\title{
African hydroclimatic variability during the last 2000 years
}

David J. Nash ${ }^{1,2^{\star}}$, Gijs De Cort ${ }^{3,4}$, Brian M. Chase ${ }^{5}$, Dirk Verschuren ${ }^{4}$, Sharon E. Nicholson ${ }^{6}$, Timothy M. Shanahan ${ }^{7}$, Asfawossen Asrat $^{8}$, Anne-Marie Lézine ${ }^{9}$, Stefan W. Grab ${ }^{2}$

1 School of Environment and Technology, University of Brighton, Lewes Road, Brighton BN2 4GJ, United Kingdom.

2 School of Geography, Archaeology and Environmental Studies, University of the Witwatersrand, Private Bag 3, Wits 2050, South Africa.

3 Department of Earth Sciences, Royal Museum for Central Africa, Leuvensesteenweg 13, 3080 Tervuren, Belgium

4 Limnology Unit, Department of Biology, Ghent University, K.L. Ledeganckstraat 35, 9000 Ghent, Belgium.

5 Centre National de Recherche Scientifique, UMR 5554, Institut des Sciences de l'Evolution de Montpellier, Université Montpellier, Bat.22, CC061, Place Eugène Bataillon, 34095 Montpellier, cedex5, France.

6 Department of Earth, Ocean and Atmospheric Science, Florida State University, Tallahassee, P.O. Box 3064520, Florida FL32306-4520, USA.

7 Department of Geological Sciences, University of Texas at Austin, EPS RM 1.130, 1 University Station C9000, Austin, Texas TX78712-0254, USA.

8 School of Earth Sciences, Addis Ababa University, P.O. Box 1176, Addis Ababa, Ethiopia.

9 Sorbonne Universités, UPMC, University Paris 06, CNRS-IRD-MNHN, LOCEAN/IPSL Laboratory, 4 Place Jussieu, 75005 Paris, France

* Corresponding author - email: d.j.nash@brighton.ac.uk 


\begin{abstract}
The African continent is characterised by a wide range of hydroclimate regimes, ranging from humid equatorial West Africa to the arid deserts in the northern and southern subtropics. The livelihoods of much of its population are also vulnerable to future climate change, mainly through variability in rainfall affecting water resource availability. A growing number of data sources indicate that such hydroclimatic variability is an intrinsic component of Africa's natural environment. This paper, co-authored by members of the PAGES Africa 2k Working Group, presents an extensive assessment and discussion of proxy, historical and instrumental evidence for hydroclimatic variability across the African continent, spanning the last two millennia. While the African palaeoenvironmental record is characterised by spatially disjunctive datasets, with often less-than-optimal temporal resolution and chronological control, the available evidence allows the assessment of prominent spatial patterns of palaeomoisture variability through time. In this study, we focus sequentially on data for six major time windows: the first millennium AD, the Medieval Climate Anomaly (900-1250 CE), the Little Ice Age (1250-1750 CE), the end of the LIA (1750-1850 CE), the Early Modern Period (1850-1950), and the period of recent warming (1950 onwards). This results in a continentwide synthesis of regional moisture-balance trends through history, allowing consideration of possible driving mechanisms, and suggestions for future research.
\end{abstract}

\title{
Keywords
}

Africa; Holocene; palaeoclimatology; Little Ice Age; Medieval Climate Anomaly 


\section{Introduction}

From humid equatorial West Africa to the arid deserts in the northern and southern subtropics, the African continent is characterised by a wide range of hydroclimate regimes (Figure 1 ). Determining the full range of natural climate variability on temporal and spatial scales relevant to ecosystem functioning and human well-being is of utmost importance to anticipate the impact of, and improve the preparedness of communities to, future climate change. Efforts to synthesise continent-specific patterns of climate change over the past two millennia have made good progress (mainly focused on temperature, e.g. Nicholson et al., 2013; PAGES 2k Consortium, 2013, 2015). However, regional to continent-scale patterns of past hydroclimate variability remain less well documented, especially for the tropics and the Southern Hemisphere.

Africa is cited by the Intergovernmental Panel on Climate Change as a continent where proxy-based climate reconstructions are currently too limited to support regional climate change assessments (Masson-Delmotte et al., 2013). Indeed, time series of temperature- or moisture-related climate variables spanning (a significant portion of) the last two millennia with adequate temporal resolution and age control remain sparse (see Neukom and Gergis, 2012; Nicholson et al., 2013; PAGES 2k Consortium, 2013), and display a highly uneven spatial distribution (Verschuren, 2004). This is partly because the classic high-resolution archives of tree rings and ice cores are mostly lacking. Tree species suitable for dendroclimatological reconstruction are few, because many local climates fail to drive the strong seasonal variation in wood growth required to produce reliable annual rings, and because trees which do grow annual rings most often do not preserve long after death (Dunbar and Cole, 1999). The potential of continuous and reliably dated ice core records is also limited, given that the only centres of glaciation (Mt Kilimanjaro, Mt Kenya, the Rwenzori range) are small and rapidly shrinking (e.g. Thompson et al., 2002).

Across much of Africa, lake-sediment records are the most important source of evidence on past climate change. However, only a small sub-set of those studied combine adequate hydrological sensitivity with demonstrably continuous sediment accumulation over the past 2000 years (Verschuren, 2003). Frequently, the timing and duration of successive wet and dry episodes is uncertain because desiccation horizons, cryptic hiatuses and large changes in sedimentation rate modify the depth-time relationship beyond what can be constrained by ${ }^{14} \mathrm{C}$ dating (Verschuren and Russell, 2009). In a large swathe of western tropical Africa, lake-based climate-proxy records with high temporal resolution are scarce because the shallow ponds and marshes dotting the region dried out during sub-recent drought episodes, while depositional environments along rivers are too dynamic to have preserved high-quality sediment records. Hence, there are currently still only a handful of well-dated records spanning the last 2000 years with robust climate signals at inter-annual to decade-scale resolution. 
In southern Africa, where there is limited potential for high-quality lake-sediment records, a diverse range of other climate archives, including speleothems (e.g. Holmgren et al., 2003) and more recently hyrax middens (e.g. Chase et al., 2012), have been explored. Pollen records of past vegetation change extracted from lake and swamp sediments are often poorly dated with low temporal resolution, and the complex nature of the region's flora can create fossil pollen assemblages that are difficult to interpret in terms of past shifts in climate regimes (e.g. Nash et al., 2006; Meadows et al., 2010; Chase et al., 2015). Previous reviews of climate change in southern Africa during the last few millennia (e.g. Tyson and Lindesay, 1992; Tyson et al., 2000) have drawn heavily on stable carbon and oxygen ratios $\left(\delta^{13} \mathrm{C}, \delta^{18} \mathrm{O}\right)$ from speleothems. However, these data also prove difficult to interpret, as the records reflect multifactorial influences that hinder clear palaeoclimatic reconstructions (see below).

The above-mentioned continental climate archives are supplemented by a small number of marine sediment cores and shell middens (e.g. Holz et al., 2007). Altogether, the spatial coverage of African palaeoclimate records remains at least an order of magnitude less than that in Europe or North America (Figure 1). With instrumental weather data beginning only in the late $19^{\text {th }}$ or early $20^{\text {th }}$ century for much of the continent (Nicholson et al., 2012a; Nicholson et al., 2012b), climate-related information gleaned from documentary sources covering the last 2-3 centuries constitutes a crucial bridge between instrumental and palaeodata concerning hydroclimate variability at (multi-)decadal timescales.

This paper represents the concerted effort by members of the PAGES (Past Global Changes) Africa 2k Working Group to (a) compile, and assess the quality of, currently available high-resolution datasets on hydroclimatic variability from across the African continent spanning the last 2000 years, and (b) combine them into a pan-African synthesis. Where possible, we direct our attention to reconstructions displaying the highest degree of continuity and most robust signatures of past hydroclimate change in well-understood climate indicators (proxies). While the currently available data have shortcomings in terms of quality and geographical coverage (we note, for example, an absence of high resolution records for Madagascar spanning the last two millennium), they exhibit sufficient spatial coherence to justify exploration of the synchrony of temporal patterns between Africa's major climate regions.

In the synthesis below (section 4), we focus sequentially on evidence pertaining to each of six major time windows recognised within the last 2000 years: the first millennium CE, the Medieval Climate Anomaly (MCA; 900-1250 CE), the Little Ice Age (LIA; 1250-1750 CE), the end of the LIA (1750-1850 CE), the Early Modern Period (1850-1950), and the period of recent warming (from 1950 onwards). In the time periods since the end of the LIA, an increasing proportion of evidence on past hydroclimate variability is derived from historical documents and instrumental time series. 


\section{Regional climate dynamics of the African continent}

Africa spans some $70^{\circ}$ of latitude, so that both mid-latitude and tropical meteorological regimes prevail in various parts of the continent. At the warm-temperate northern and southern extremes, rainfall is mainly linked to the frontal systems of the mid-latitude westerlies, which reach Africa in the winter of the respective hemisphere (Figure 1). In tropical areas, a broad region of rainfall shifts latitudinally throughout the year, trailing the zone of maximum solar insolation. This rain belt reaches its poleward extremes during the summer of the respective hemisphere, passing twice through the equatorial latitudes (Figure 1, bottom). Consequently, the seasonal cycle of rainfall tends to be unimodal (with a single peak in the summer) in the outer-tropical latitudes, and bimodal (with peaks during the two transition seasons) near the equator. In between the mid-latitude and tropical regimes, deserts or semi-arid regions prevail. In addition to these general climate mechanisms, factors such as topography and maritime influences create complex patterns of regional rainfall, controlled by diverse dynamic causes (Nicholson, 2000). Much rainfall in the subtropical latitudes is associated with systems that develop from the interaction of the tropical and mid-latitude regimes, diagonal cloud bands, and cutoff lows (van Heerden and Taljaard, 1998; Todd and Washington, 1999; Knippertz and Martin, 2005, 2007; Hart et al., 2010). These often bring unseasonal rainfall to West and North Africa, as well as much of the summer rainfall over southern Africa.

The tropical rain belt was traditionally referred to as the Intertropical Convergence Zone (ITCZ); however, the rainfall maximum is not necessarily linked to this zone of surface convergence (Zhang et al., 2006; Nicholson, 2009). This is particularly true over West Africa, where the rainy season is a consequence primarily of large, westward migrating mesoscale features associated with the African Easterly Jet of the mid-troposphere (Mohr and Thorncroft, 2006). Over equatorial Africa, orography exerts a major influence, with the terrain-induced low-level Turkana Jet playing a significant role in the relative dryness of eastern areas (Obwang et al., 2014; Nicholson, 2015). Over the Congo Basin, mesoscale disturbances related to the terrain-induced diurnal cycle of wind are the dominant rain-producing system (Nesbitt et al., 2000; Zipser et al., 2006), and are likewise influenced by a mid-level easterly jet stream (Jackson et al., 2009). As such, we recommend that the interchangeable use of the ITCZ for the tropical rain belt in Africa be discontinued.

Over West Africa, rainfall is part of a monsoon system created largely by the thermal contrast between the Sahara and the cooler Atlantic to the south (Thorncroft et al., 2011). This system connects the Sahel, with its unimodal seasonality, and the Guinea Coast, where rainfall is bimodal. The monsoon rain belt generally lies over the Guinea Coast in the boreal spring and autumn, but over the Sahel in the boreal summer. Thus, year-to-year variability in these regions is closely coupled, and strongly influenced by sea surface temperature (SST) variability in the Atlantic (Camberlin et al., 2001; Zhang and Delworth, 2006; Losada et al., 
2010). However, SSTs in the Mediterranean (Rowell, 2003) and Indian Ocean (e.g. Bader and Latif, 2003), and El Niño (e.g. Losada et al., 2012), are also significant influences.

An important factor in year-to-year variability is the inter-hemispheric temperature gradient (Hoerling et al., 2006). Palaeodata and modelling studies have demonstrated the sensitivity of the West African monsoon to abrupt and sustained shifts in moisture at longer time scales, similarly driven by changes in the latitudinal gradient of Atlantic SSTs (Giannini et al., 2003; Liu et al., 2004; Shanahan et al., 2009) and positive land-surface and vegetation feedbacks on monsoon intensity (Kutzbach and Otto-Bliesner, 1982; Street-Perrott and Perrott, 1990; Claussen et al., 1999; deMenocal et al., 2000; Gasse, 2000; Renssen et al., 2006; Shanahan et al., 2015). Latitudinal gradients in sea-level pressure and the intensity of the Saharan heat low are related factors (Nicholson and Webster, 2007).

Over most of eastern Africa, the rainfall pattern is bimodal, although in some areas of the northern and western extremes, the season transitions to a single peak regime with a boreal summer maximum. In much of the region, the two rainy seasons are termed the "long rains" (which generally prevail March-May, but with local variations, e.g. in the Ethiopian Highlands) and the "short rains" (October-November; Nicholson, 2011). To the west of the region is a lowlevel convergence zone termed the Congo Air Boundary (CAB). It is most often situated along the mountainous western shoulder of the East African Rift System. To the west, Atlanticderived moisture contributes significant rainfall to Ethiopia, the western part of the East African plateau, and the Kenya highlands (Mapande and Reason, 2005; Levin et al., 2009). In contrast, easternmost equatorial East Africa and the Horn of Africa receive virtually all their precipitation from the Indian Ocean.

On interannual timescales, the amount and intensity of the "short rains" displays a strong correlation to Indian Ocean SSTs, which themselves are greatly influenced by the EI Niño Southern Oscillation (ENSO) and the Indian Ocean Dipole (IOD; Saji et al., 1999). Warming in the western Indian Ocean associated with EI Niño conditions and a positive IOD lead to higher rainfall over equatorial eastern Africa (Goddard and Graham, 1999). The mechanism in both cases is the intensity of the low-level westerly flow over the equatorial Indian Ocean. These westerlies are the most robust factor in the variability of the "short rains" (Nicholson, 2015). The mechanism of influence is a modulation of the Indian Ocean Walker cell, with stronger westerlies enhancing this cell and thereby strengthening subsidence over eastern Africa. Our understanding of the "long rains" is less definitive, but they are clearly much less correlated to ENSO or any other large SST anomaly (Ogallo et al., 1988; Hastenrath et al., 1993; Okoola, 1999; Pohl and Camberlin, 2011) operating at the interannual to sub-decadal time scale. One factor appears to be the relative warming of the Indian Ocean compared to the Pacific (Williams and Funk, 2011); this affects the east-west Walker circulation cell over the Indian Ocean, which modulates vertical motion over eastern Africa. 
Southern Africa spans the interface between tropical climate systems and those associated with the Southern Hemisphere westerlies (Tyson, 1986; Preston-Whyte and Tyson, 1993; Tyson and Preston-Whyte, 2000). In interior and eastern areas, precipitation is rare during winter, as continental cooling causes the development of a high-pressure cell. Here, most rain falls during the summer as continental and sea-surface temperatures increase, resulting in the accession of moist air from the southwestern Indian Ocean (Reason and Mulenga, 1999). Over eastern portions of southern Africa, as much as $20 \%$ of the summer rainfall is associated with large mesoscale convective complexes. These have little impact in Botswana or Namibia (Blamey and Reason, 2013). Cutoff lows occasionally bring torrential rainfall to eastern regions, particularly in autumn and spring (van Heerden and Taljaard, 1998).

In contrast, in the southwestern Cape, an equatorward shift of the westerly storm track results in the greater influence of associated frontal systems during winter months. In the summer, as the westerlies shift poleward, climate is instead dominated by the South Atlantic High, suppressing uplift and creating extended drought (Tyson, 1986; Preston-Whyte and Tyson, 1993). Transitional between the summer and winter rainfall zones is a zone of aseasonal rainfall. Climate here varies from arid along the western Orange River valley and the Namibian coast, to humid along the southern Cape coast.

While the temperate and tropical systems are often considered distinct, interaction between them does occur, when strong frontal systems may combine with tropical circulation to induce substantial convective precipitation systems across the subcontinent (Tyson, 1986). Consequently, over much of southern Africa, a large portion of the precipitation is associated with hybrid systems that combine the characteristics of frontal and convective rainfall. One of the most common is the "tropical-temperate trough" (also called a cloud band, diagonal trough or tropical plume; Todd and Washington, 1999; Hart et al., 2010). These extend diagonally between a trough in the upper-level westerlies and a low-level tropical vortex.

Despite the complexity of these regional factors in precipitation, interannual and decadal variability is continental in scale. This is because of the ubiquitous influence of the upper level winds (e.g. the mid-latitude westerlies and tropical easterlies), the latitudinal gradients of insolation, and the seasonal cycle of SSTs. These all have manifestations at the regional scale. For example, over centennial to multi-millennial timescales, varying dominance of the tropical and temperate systems causes significant change in the climatic conditions of this region (van Zinderen Bakker, 1976; Cockcroft et al., 1987; Chase and Meadows, 2007).

\section{The Holocene context}

Hydroclimate variability across Africa during the last 2000 years must be considered in the context of longer-term Holocene trends. Over the last 11,700 years, most regions experienced substantial changes in moisture balance, which at the multi-millennial time scale are believed 
to have been controlled mostly by changes in local solar insolation associated with the Earth's precessional cycle (Kutzbach, 1981; Kutzbach and Liu, 1997; Joussaume et al., 1999; Braconnot et al., 2000). During the early Holocene, northern hemisphere summer insolation was at a maximum, resulting in much wetter conditions than today throughout northern subtropical and tropical Africa (Vincens et al., 1999; Gasse, 2000; Hoelzmann et al., 2001; Asrat et al., 2007; Umer et al., 2007; Lézine et al., 2011b; Lézine et al., 2013; Tierney and deMenocal, 2013; Foerster et al., 2015; Shanahan et al., 2015). With Earth's perihelion gradually shifting to Southern Hemisphere summer over the course of the Holocene, proxy records from this region show a time-transgressive deterioration of moisture balance toward a dry late Holocene (Lézine et al., 2011b; Shanahan et al., 2015).

In eastern Africa, all sites north of the equator, as well as many sites further south (to about $10^{\circ} \mathrm{S}$ ), seem to have followed the general pattern dictated by Northern Hemisphere summer insolation (Gasse, 2000; Barker et al., 2002). Wetter conditions there during the early Holocene are attributed to the combination of increased Indian Ocean sourced rainfall associated with high SSTs in the western Indian Ocean (Tierney et al., 2008), with increased dry-season precipitation (Tierney et al., 2011b) due to an enhanced influx of Atlantic Ocean derived moisture via the Congo basin (Schefuß et al., 2005). However, the most eastern sector of equatorial Africa - which is situated east of the CAB year-round and hence relatively isolated from Atlantic Ocean influence - experienced a characteristic 'hybrid north/south' pattern, with a very wet early Holocene, a dry mid-Holocene, and modestly wet conditions during the last $\sim 4000$ years (Verschuren et al., 2009). Further, in more western sectors of the East African plateau, the driest conditions of the entire Holocene seem to have been registered already around 2000 years ago, followed by a modest long-term wetting trend since then (Verschuren and Charman, 2008; see also section 4.1 below).

In southeastern Africa (i.e. south of $10^{\circ} \mathrm{S}$ ), some records show the expected inverse pattern, i.e. an orbitally-driven early Holocene drought followed by generally wetter late Holocene conditions (Castaneda et al., 2007; Schefuß et al., 2011; Truc et al., 2013; Chevalier and Chase, 2015). However, in southwestern Africa, a largely in-phase relationship between the hemispheres has been found (Chase et al., 2009; Chase et al., 2010; Collins et al., 2011), contradicting the prediction of orbitally-driven north-south anti-phasing in Holocene hydroclimate trends. In the temperate mid-latitude region of the southern Cape, a long-term trend toward more humid conditions seems to have been concurrent with generally cooler conditions since the mid-Holocene (Chase and Meadows, 2007; Chase et al., 2013). However, more precise higher-resolution records from this region are required before robust conclusions can be drawn. Together, these longer-term climate trends imply that in most, but clearly not all, regions of Africa, changes in hydroclimate over the last 2000 years are superimposed on a general long-term decline in moisture availability. 


\subsection{The first millennium of the Common Era}

Two thousand years ago, the Sahara of North Africa was already an arid desert subject almost year-round to dry north-northeasterly trade winds. Sediment data from Lake Yoa in northern Chad (Kröpelin et al., 2008), the only demonstrably continuous palaeohydrological archive from the central Sahara, is generally uninformative on the region's hydroclimatic variability within the last two millennia. However, two drier phases can be determined from pollen and spore data at the site, from c. 540 BCE to 160 CE and from c. 460 CE to 760 (Lézine et al., 2011a). A rare record from the northwest Sahara, discontinuous and based on ring-width variations in ${ }^{14} \mathrm{C}$-dated Cupressus dupreziana (cedar) from the Tassili n'Ajjer (southeastern Algeria), also shows a reduction in multi-decadal to century-scale rainfall variability coincident with apparent drying from c. 500-750 CE (Cremaschi et al., 2006) (Figure 2).

Well-dated and informative climate-proxy records for this period from West Africa are mostly from the humid western and equatorial parts of the subcontinent (Figure 1) near the Atlantic coast (Figure 2). At Lake Bosumtwi (Ghana), lake-carbonate $\delta^{18} \mathrm{O}$ variations indicate that, after a c. 900-year period of relatively moist conditions, an abrupt shift toward greater aridity c. 250 CE was followed by a sustained gradual trend toward drier conditions continuing until the end of the first millennium (c. 950 CE; Shanahan et al., 2009). The onset of this drying trend is supported by a marine dust record from offshore Senegal (GeoB9501), which indicates that starting c. $100 \mathrm{CE}$ and continuing through the first millennium, the western Sahel region experienced gradual drying and loss of vegetation cover (Mulitza et al., 2010). At Kajemarum Oasis in semiarid northeastern Nigeria, variations in ostracod shell $\mathrm{Sr} / \mathrm{Ca}$ and $\delta^{18} \mathrm{O}$ indicate a first phase of drying c. 300-0 BCE and a later phase of more prominent drying starting between c. $500 \mathrm{CE}$ and 650 (Street-Perrott et al., 2000). The slight differences in the timing and rate of change in the $\mathrm{Sr} / \mathrm{Ca}$ and $\delta^{18} \mathrm{O}$ records from this site likely reflect differences in how each proxy exactly traces local hydrological change. For example, while Sr/Ca and $\delta^{18} \mathrm{O}$ in lacustrine carbonates are both dominated by changes in salinity, other factors may influence the $\delta^{18} \mathrm{O}$ of lacustrine carbonates, such as changes in source precipitation $\delta^{18} \mathrm{O}$ (Rozanski et al., 1992) and the temperature of carbonate formation (Kim and O'Neil, 1997). Nevertheless, the most intense drought recorded in the Sr/Ca data, dated to c. 750-1000 CE, is also evident in the desiccation of neighbouring lakes (Holmes et al., 1999) and a large salinity increase at Bougdouma Oasis in Niger (Gasse and van Campo, 1994), suggesting a robust regional phenomenon.

In the transition zone between the northern unimodal and equatorial bimodal rainfall zones, a low-resolution diatom record from Lake Tizong, northern Cameroon, documents a significant lowstand between c. 450 CE and 850 (Nguetsop et al., 2013), consistent with fossil pollen data from the same site showing expansion of grassland starting c. 500 CE after a c. 800-year 
long phase of forest growth. At nearby Lake Mbalang, a corresponding lowstand is centred on c. 550 CE (Nguetsop et al., 2011). The timing of these transitions is more or less synchronous with the drying inferred at Kajemarum Oasis.

Farther south, at Lake Bambili in the mountains of western Cameroon, the percentage tree pollen indicates stable moist conditions from 250 BCE until $500 \mathrm{CE}$, followed by an abrupt shift to more open vegetation c. 500 CE (Lézine et al., 2013). Recovery of the forest between c. 600 CE and 950 (Lézine et al., 2013) suggests that the inferred drought was relatively shortlived, and that wetter conditions prevailed again toward the end of the first millennium. A diatom-based lake-level reconstruction from Lake Ossa, near the Atlantic Ocean coast another $250 \mathrm{~km}$ further south, does not show any strong signal during the first millennium CE, whereas it does provide evidence for a lowstand in the late first millennium BCE, more or less synchronous with inferred drought at Kajemarum Oasis (cf. Nguetsop et al., 2010).

Proxy records from Atlantic West Africa around and immediately south of the equator (e.g. Ngomanda et al., 2007), although incomplete for this period, reveal a distinctly different temporal pattern of hydroclimate change compared to sites further north. Pollen-based moisture-balance reconstructions from lakes Nguène and Kamelété, Gabon, indicate that the driest conditions of the last 2000 years occurred before 500 CE and 700, respectively, and that humidity gradually increased to peak around 750 CE (Nguene) or toward the end of the first millennium (Kamelété). The strongest evidence for this wetting trend is an expansion of the tropical rainforest (Ngomanda et al., 2007). Time series of a sedimentary clay-weathering index from Lakes Kitina and Sinnda in southern Congo, though of limited temporal resolution and/or incomplete, similarly suggest a shift to wetter conditions toward the end of the first millennium (cf. Bertaux et al., 2000). Pollen from Lake Sinnda show a similar trend (Vincens et al., 1998).

Most lake records from eastern Africa (Figure 3) suggest that the region experienced a century-scale episode of pronounced aridity shortly before, and around the start of, the Common Era, possibly the driest period of the middle-late Holocene (Verschuren and Charman, 2008). Variation in the carbonate content of sediment cores from the northern part of Lake Turkana, reflecting Omo River inflow and thus precipitation over the Ethiopian highlands, indicates that several arid events occurred between c. 200 BCE and 300 CE (Halfman et al., 1994). A lake-level reconstruction for Lake Tanganyika based on fossil ostracod assemblages suggests that its lowest level of the past 2500 years was reached between 200 BCE and 0 CE (Alin and Cohen, 2003). Stromatolite $\delta^{18} \mathrm{O}$ data and ancient shorelines similarly suggest relatively dry conditions in the Tanganyika basin from 200 BCE until c. $200 \mathrm{CE}$, but they contrast with the ostracod evidence in situating the driest episode of the last 2000 years within the last 400 years, i.e. during the Little Ice Age (Cohen et al., 1997). On the other hand, a high-resolution record of diatom-inferred conductivity (dissolved-ion 
content) from northern Lake Tanganyika (Stager et al., 2009) displays little evidence of either of these drought episodes. Instead it shows a more or less sustained decreasing trend in mean water-residence time over the past 3300 years, implying a general trend of climatic wetting throughout this period.

In the central Kenya Rift Valley, the deep Crescent Island Crater basin of Lake Naivasha last stood dry c. 200 CE (Verschuren, 2001). In western Uganda, peak \%Mg levels of calcite deposited in Lake Edward point to a distinct century-scale phase of intense evaporation centred on c. 100 CE (Russell and Johnson, 2005), evidence for pronounced regional aridity that has also been recorded at three nearby Ugandan crater lakes (Russell et al., 2007). At Sacred Lake on the lower slopes of Mt. Kenya, high (less depleted) $\delta D$ values in plant leaf waxes indicate increased aridity shortly before 300 CE (Konecky et al., 2014). Finally, at Lake Challa near Mt. Kilimanjaro, a shift to generally low values of the Branched to Isoprenoid Tetraether (BIT) index from bacterial cell-wall lipids indicate reduced monsoonal rainfall between 0 and 200 CE (Buckles et al., 2016). The both varve-counted and wellconstrained ${ }^{14} \mathrm{C}$ chronology of the Lake Challa sediment archive (Blaauw et al., 2011; Wolff et al., 2011) adds significance to the timing of its signature for this episode of widespread aridity. Notably, the varve-thickness record from Lake Challa, which is understood to reflect rainfall variability at the inter-annual time scale rather than long-term trends (Wolff et al., 2011), does not show a corresponding signal during this period.

Following this episode of apparently widespread drought, much of eastern Africa appears to have experienced slightly wetter conditions between c. 200 CE and 600. In equatorial East Africa, this is evidenced by refilling of the previously dry Lake Naivasha, followed by a relative highstand lasting until c. 600 CE (Verschuren, 2001); and by a low ratio of nearshore versus offshore diatom taxa recorded in the sediment record of northern Lake Victoria (Stager et al., 2003). Reduced \%Mg values of Lake Edward calcite in the period 200-400 CE (Russell and Johnson, 2005) document similarly wet conditions on the western shoulder of the East African plateau, while at Lake Tanganyika, a contemporaneous humid phase is dated to between $\mathrm{c}$. 250 CE and 550 (Stager et al., 2009). Lake Kivu must also have experienced a positive water balance during this period, since its overflow into Lake Tanganyika via the Rusizi River was reactivated c. 550 CE (Cohen et al., 1997). At the northern extreme of eastern Africa, a diatom record from Lake Ashenge (northern Ethiopia; Marshall et al., 2009) and a potassium record from Chew Bahir (southern Ethiopia; Foerster et al., 2012; Foerster et al., 2015) indicate that relatively wet conditions also prevailed over the Ethiopian highlands during the first half of the first millennium $A D$, although age control during this period is poor in both series. Machado et al. (1998) found evidence for this inferred wet period from infilled valley deposits in the northern Ethiopian highlands. Archaeological evidence suggests a similar pattern for Lake Malawi (Owen et al., 1990). 
Available records attest to considerably greater spatial climatic variability in eastern Africa during the second half of the first millennium AD. Lake Edward experienced a succession of multi-decadal droughts, superimposed on overall low humidity levels, between $400 \mathrm{CE}$ and 890 (Russell and Johnson, 2005). Lake Tanganyika's level fell after the 250-550 CE high stand, followed by a gradual rebound toward the end of the first millennium CE (Alin and Cohen, 2003; Stager et al., 2009). At Sacred Lake on Mt. Kenya, an abrupt drought dated to c. $650 \mathrm{CE}$ was followed by a gradual recovery of precipitation to reach an inferred maximum c. 1000 CE (Konecky et al., 2014). In the northern Kenya Rift Valley, Omo River inflow to Lake Turkana was relatively high between c. 400 CE and 800 (Halfman et al., 1994), whereas a number of massive trona (sodium carbonate) deposits in the sediments of hypersaline Lake Bogoria suggests a succession of distinctly negative water-balance anomalies during the second half of the first millennium CE (De Cort et al., 2013). Further south in the Kenya Rift Valley, Lake Naivasha slipped from high to fluctuating lake levels c. 600 CE (Verschuren, 2001); in southeastern Kenya in contrast, Lake Challa experienced the wettest conditions of the past 2200 years between c. 600 CE and 1000 (Buckles et al., 2016).

Many eastern African records indicate a short but distinct period of higher rainfall toward the end of the first millennium CE. Examples include Lake Hayq c. 700 CE (Lamb et al., 2007), Lake Turkana c. 750 CE (Halfman et al., 1994), Lake Edward c. 900-1000 CE (Russell et al., 2007), Lake Tanganyika c. 800-850 CE (Alin and Cohen, 2003; Stager et al., 2009), Lake Naivasha c. 900 CE (Verschuren et al., 2000; Verschuren, 2001) and Lake Challa c. 950 CE (Buckles et al., 2016). Taking into account chronological uncertainties, these signatures may represent the same region-wide episode of inferred peak rainfall. From its inferred timing in the best-dated records (Edward, Naivasha and Challa), we venture to assign a most-probable date of the $10^{\text {th }}$ century CE.

In southern Africa, few high-resolution records are sufficiently well-dated to adequately address palaeoclimate questions at sub-millennial timescales (Figure 4). Exceptions are speleothem $\delta^{18} \mathrm{O}$ records from Cango Cave (Talma and Vogel, 1992) and Cold Air Cave (Repinski et al., 1999; Stevenson et al., 1999; Lee-Thorp et al., 2001; Holmgren et al., 2003), South Africa. These records have long defined regional climate change narratives (Tyson and Lindesay, 1992; Tyson et al., 2000), but their interpretation remains a matter of discussion (see Lee-Thorp et al., 2001; Holmgren et al., 2003; Chase et al., 2010; Stager et al., 2013; Sundqvist et al., 2013; Woodborne et al., 2015). More recent $\delta^{13} \mathrm{C}$ records from baobab trees (Adansonia digitata) at Pafuri in northernmost South Africa, indicate that a negative relationship exists between Cold Air Cave $\delta^{18} \mathrm{O}$ and baobab $\delta^{13} \mathrm{C}$ at centennial time scales over the last millennium (Woodborne et al., 2015). Using the palaeotemperature reconstruction of Sundqvist et al. (2013), these data suggest that, during this period, variation in Cold Air Cave $\delta^{18} \mathrm{O}$ may indeed have been driven primarily - but perhaps not exclusively 
(e.g. Stager et al., 2013) - by temperature, and that warmer conditions generally correlated with increased regional humidity. The Pafuri data further support Holmgren et al.'s (2003) interpretation of Cold Air Cave $\delta^{13} \mathrm{C}$ data. Combined, they suggest highly variable conditions during the late Holocene in northeast South Africa, with a general trend toward more arid conditions over the last 2000 years, with phases of relatively humid conditions from $300 \mathrm{BCE}$ to $50 \mathrm{CE}$ and $530-900 \mathrm{CE}$.

In Namibia, records from hyrax middens at Spitzkoppe (Chase et al., 2009) and speleothems in Dante's Cave (Sletten et al., 2013) indicate relatively stable dry or drying conditions from 1000 BCE to c. 200 CE. At Spitzkoppe, episodes of increased humidity around $200 \mathrm{CE}$ and 550 (Chase et al., 2009) may relate to $\delta^{18} \mathrm{O}$ and growth-rate indications for increased rainfall at Dante's Cave from 200-800 CE (Sletten et al., 2013). Over the time period considered here, it appears that the western portion of the summer rainfall zone experienced perturbations generally out-of-phase to those observed in the east, with a broad negative relationship between the records from Spitzkoppe and Dante's Cave and the Cold Air Cave speleothem.

In the winter rainfall zone of South Africa's Western Cape, rock-hyrax midden $\delta^{15} \mathrm{~N}$ records from Seweweekspoort (Chase et al., 2013) indicate a long-term humidity increase throughout the last two millennia. This trend also seems to be reflected in Cango Cave $\delta^{13} \mathrm{C}$ variation (either as a function of an increase in $\mathrm{C} 3$ grasses or variations in water-use efficiency under more humid conditions; cf. Chase et al., 2013), and the Verlorenvlei diatom record, which indicates increased freshwater input over the last 1400 years (Stager et al., 2012). Although a greater number of highly resolved records is required to draw robust conclusions, it appears that a generally in-phase relationship may exist between the southwestern Cape and the western summer rainfall zone, with both exhibiting signals in opposition to those observed in the eastern summer rainfall zone. This is consistent with the findings of Chevalier and Chase (2015), who identified a north-south dipole within the eastern summer rainfall zone during recent millennia.

\subsection{The Medieval Climate Anomaly (950 - 1250 CE)}

Around the transition between the first and second millennium CE - a period widely referred to as the MCA (Jones et al., 2001; Matthews and Briffa, 2005) - high northern-latitude regions experienced mostly warm conditions (Figure 2). Hemisphere-wide and global syntheses (Moberg et al., 2005; Mann et al., 2008; PAGES 2k Consortium, 2013) suggest that this period was generally warmer than the subsequent LIA. However, the nature and timing of the MCA temperature departure is now recognised as being spatially complex, and distinct at the scale of different continents (Jones and Mann, 2004; PAGES 2k Consortium, 2013). The few existing temperature reconstructions from Africa with adequate resolution in the last 2000 
years suggest a generally warm MCA, but do not allow comprehensive assessment of the continent's temperature variability during this period (Jones and Mann, 2004; Nicholson et al., 2013; PAGES 2k Consortium, 2013). Evidence describing the nature of Africa's hydroclimate during the MCA is more extensive, but some geographical gaps remain.

A synthesis of historical sources indicates that the MCA was wetter than today all across the Sahel (Nicholson, 1979). According to this study, between the $9^{\text {th }}$ and $13^{\text {th }}$ century AD, several towns in Mauritania are said to have flourished on caravan trade. Their locations, and those of the routes upon which they were founded, suggest wetter conditions. This is consistent with the agricultural practices of the Gangara people who occupied the sandy plains of Assaba and the Tagant in Mauritania from the $8^{\text {th }}$ to the $15^{\text {th }}$ century AD, and practiced wet cultivation in areas where present-day aridity makes this impossible. Around the $11^{\text {th }}$ century $A D$, the water level in wells of the caravan city of Awdaghast (Tedgaoust) was some $8 \mathrm{~m}$ higher than today. Evidence from Senegal and Niger suggests that sand dunes were fixed by vegetation about the same time, with conditions sufficiently stable that tombs were built on top of them near Rao, Senegal (Nicholson, 1980). These humid conditions may have extended as far as the limit of African monsoon penetration in northern Chad. The Tibesti mountain massif appears to have become depopulated in the $10^{\text {th }}$ through $13^{\text {th }}$ centuries, indicating that conditions were wet enough to sustain its population in the surrounding plains.

The history of Lake Chad over the past 900 years (Maley, 1973) has been revised and updated several times. Compilation of the sedimentological and palynological data (Maley, 1981), anchored in three radiocarbon dates (Maley, 1993) and tuned with available documentary proxy data (Maley, 1989), indicate that the lake stood high from before $1100 \mathrm{CE}$ to 1400 and again in the $17^{\text {th }}$ century, separated by low to intermediate levels during the $15^{\text {th }}$ and $16^{\text {th }}$ centuries. Slightly wetter conditions in this region from 1000 to $1200 \mathrm{CE}$ are also apparent in $\mathrm{Sr} / \mathrm{Ca}$ and $\delta^{18} \mathrm{O}$ data (Figure 2) from carbonates in Lake Kajemarum (northeastern Nigeria; Street-Perrott et al., 2000). Additional evidence that relatively humid conditions extended to the easternmost Sahel include the presence of elephants and giraffes near Dongola in Sudan during the $12^{\text {th }}$ century (present annual rainfall $\sim 20 \mathrm{~mm}$ ), and extensive pilgrim traffic across the Red Sea during the $13^{\text {th }}$ century from a port (probably Port Sudan) which was later abandoned for lack of drinking water (Nicholson, 1979).

In the more humid regions south of the Sahel (Figure 2), the MCA appears to have been a period of relative aridity. Dry conditions from c. 900 CE to 1150 are evident in lake level and stable isotope data from Lake Bosumtwi (Shanahan et al., 2009), and in peak dust flux in marine sediment core GeoB9501 from offshore Senegal (Mulitza et al., 2010). To the east, in Cameroon, Lake Bambili also records a rapid shift from forest to a more open landscape at around 900 CE. However, pollen data indicate that forest did not recover until c. $1500 \mathrm{CE}$, suggesting that dry conditions lasted much longer than at sites further west (Lézine et al., 
2013). Additional support for an extended dry interval originating during the MCA comes from Lake Ossa, where an increase in the proportion of alkaliphilous diatoms (interpreted as decreased precipitation) places the most arid conditions of the past 2700 years between $\mathrm{c}$. 950 CE and 1150 (Nguetsop et al., 2010). Slightly to the north, at Lakes Tizong and Mbalang (Vincens, 2010; Nguetsop et al., 2013), pollen data indicate that open conditions were maintained throughout the last c. 1500 years. However, at Tizong, the onset and termination of the MCA is characterised by two periods of increasing arboreal pollen, possibly suggesting slightly wetter conditions. In the southern Congo, the signal is more complex. Overall, conditions appear to have become wetter c. 700-800 CE, just before the MCA. At lakes Kamelété (Ngomanda et al., 2007) and Sinnda (Bertaux et al., 2000), pollen and weathering indicators suggest that humid conditions were maintained during subsequent centuries, with no change during the MCA. Similarly, at Lake Kitina, clay weathering indicators suggest wetter conditions from 900-1250 CE (Bertaux et al., 2000). In contrast, the pollen record from Lake Nguène indicates a shift to a more open landscape from 800-1400 CE (Ngomanda et al., 2007).

The combined information from sites across eastern Africa (Figure 3), from Ethiopia in the north to Lake Malawi in the south, points to generally drier-than-average conditions during the MCA. The onset of the MCA was marked by a dramatic increase in the frequency of extremely low Nile River floods in Egypt, reflecting reduced rainfall over headwaters on the Ethiopian plateau and the wider Lake Victoria catchment (Hassan, 2007). Low Nile floods remained common until $1350 \mathrm{CE}$, but were interrupted by an interval of high discharge between 1070 $\mathrm{CE}$ and 1180. Historical reports of widespread famine at that time cover the entire Nile catchment, from Egypt (Hassan, 2007) to headwater areas around Lake Victoria (Webster, 1979). A diatom-based lake-level reconstruction from Lake Victoria starting around $1000 \mathrm{CE}$, suggests relatively dry conditions during the MCA, with drought culminating in a c.100-year episode centred on 1200 CE (Stager et al., 2005). The carbonate concentration in Lake Turkana sediments reflects reduced river input from the Ethiopian highlands during the period c. 900-1200 CE (Halfman et al., 1994), consistent with enriched $\delta^{18} \mathrm{O}$ of authigenic carbonate deposited in Lake Hayq in northern Ethiopia between c. 800 CE and 1200 (Lamb et al., 2007). Lake Naivasha was also low during most of the interval 1000-1250 CE (Verschuren et al., 2000). On the western shoulder of the East African plateau, Lake Edward experienced a distinct drying trend over the course of the MCA, with most pronounced drought c. $1050 \mathrm{CE}$ and after 1150 CE, and again ending c. 1200 CE (Russell and Johnson, 2007). This drought is also recorded at several maar crater lakes in western Uganda (Russell et al., 2007; Mills et al., 2014). At Lake Tanganyika, the MCA seems to have been a period of declining humidity, culminating in drought dated to c. 1150 CE (Alin and Cohen, 2003; Stager et al., 2009). In the southern part of eastern Africa, Lake Malawi experienced a major regression between 1150 CE and 1250 (Owen et al., 1990). In easternmost equatorial East Africa, the Lake Challa BIT- 
index record suggests that an abrupt aridification between $1150 \mathrm{CE}$ and 1200 resulted in peak MCA drought, which continued until 1300 CE (Buckles et al., 2016).

Notwithstanding the broad coherence in medieval drought across eastern Africa, temptation should be resisted to treat the MCA as a single 300-year dry event. The sediment records of several relatively shallow endorheic lakes, such as Naivasha, may be discontinuous across this interval, precluding precise statements on the exact timing and duration of MCA drought, and possible short-term variability within this period (Verschuren and Charman, 2008). The certifiably continuous records (Edward, Victoria, Tanganyika, Challa) all seem to suggest that MCA drought peaked in the second half of the $12^{\text {th }}$ century.

Several records from southern Africa (Figure 4) permit the reconstruction of hydroclimates during the MCA, although as with many of the series from the first millennium $A D$, there are debates over interpretation. Using speleothem data from northeastern South Africa, Tyson and Lindesay (1992) and Tyson et al. (2000) inferred that the summer rainfall region south of Lake Malawi may have been wetter and perhaps significantly warmer than today $\left(\sim+3^{\circ} \mathrm{C}\right)$ during the MCA. However, subsequent refinements of the age model for the Cold Air Cave speleothem records indicate that conditions from c. 800 CE to 1200 were actually highly variable (speleothem T7 data; Holmgren et al., 1999; Lee-Thorp et al., 2001), or even consistently cooler (speleothem T8 data; Holmgren et al., 2003, applying palaeotemperature transfer function of Sundqvist et al., 2013). While Holmgren et al. (2003) conclude that the Cold Air Cave records provide evidence for medieval warming, the MCA sensu stricto is a period of strongly depleted $\delta^{18} \mathrm{O}$ values in speleothem T8, a situation very similar to the coldest period of the LIA. Similarities do seem to exist, however, between the Cold Air Cave T7 speleothem and Cango Cave $\delta^{18} \mathrm{O}$ records, perhaps suggesting that the muted response recorded in the $\mathrm{T} 7$ speleothem is a more accurate reflection of prevailing conditions. $\delta^{13} \mathrm{C}$ records from the $\mathrm{T} 7$ and $\mathrm{T} 8$ speleothems are more coherent, and, following the interpretations of Holmgren et al. (2003), indicate a phase of more variable, but generally mesic conditions, similar to the period BCE 1000 to $900 \mathrm{CE}$.

Warm, wet conditions from c. 900-1200 CE at the nearby site of Wonderkrater are indicated by covariance in moisture-loving taxa such as Proteaceae, Oleaceae and Combretaceae, and a reduction in drought-tolerant Chenopodiacae-Amaranthaceae compared with the first millennium CE (Scott, 1999). The temporal resolution of this record is low and it is difficult to fully situate the findings in the context of the changes occurring in the last millennia. Variability across the MCA and early LIA are, however, generally consistent with the $\delta^{13} \mathrm{C}$ records from Cold Air Cave and the Pafuri baobab series (Woodborne et al., 2015), with a peak in humidity beginning at c. $980 \mathrm{CE}$ and an inferred return to drier conditions c. $1250 \mathrm{CE}$, which ended with a return to moist conditions c. 1350 CE. Support for these hydroclimatic shifts is found in pollen 
records from across the lower Limpopo Valley, where trees become more dominant between $800 \mathrm{CE}$ and 1400, presumably in response to higher rainfall (Ekblom et al., 2012).

On the western margin of southern Africa, at Spitzkoppe, depleted $\delta^{15} \mathrm{~N}$ in rock-hyrax middens indicate greater water availability during the MCA (Chase et al., 2009). This record also shows substantial variability, with a period of generally increased humidity between 900 CE and 1250 interrupted by significantly drier conditions c. 1200 CE. This pattern correlates with records of SST and upwelling from the adjacent southeast Atlantic Ocean at marine core site ODP 1084B, where variation in the abundance of left coiling Neogloboquadrina pachyderma (Farmer et al., 2005) infer a reduction of upwelling intensity during periods of increased humidity recognised at Spitzkoppe. From the same region, pollen records from hyrax middens along the Kuiseb River valley show increases in frost-sensitive Salvadora during the MCA, with peaks around 1100 CE and 1250 suggesting warmer conditions (Scott, 1996). The similarities between these Namibian records suggest that warmer, more humid conditions prevailed during the MCA in the western summer rainfall zone. As a counterpoint, evidence from Verlorenvlei in southernmost South Africa, where precipitation is currently linked most strongly to the westerly storm track, indicates that conditions were relatively dry throughout the period 550-1300 CE (Stager et al., 2012).

\subsection{The Little Ice Age (1300 - 1750 CE)}

Analyses of glacier and palaeoclimate records have justified the distinction of an "early" LIA phase, characterised by glacier advances in the Alps from around $1300 \mathrm{CE}$ onward, and a "main" LIA phase (c. 1550-1850 CE) when mean annual Northern Hemisphere temperature fell significantly below the 1961-1990 CE mean (Matthews and Briffa, 2005). Recent palaeoclimate data syntheses (Jones and Mann, 2004; Moberg et al., 2005; PAGES 2k Consortium, 2013, 2015) indicate that the Northern Hemisphere as a whole had already experienced distinct cooling from the end of the MCA (Figure 2), but also that manifestation of LIA cooling was not uniform between continents.

Temporal patterns of precipitation during the LIA vary across Africa. Numerous lines of evidence suggest that the Sahel and nearby regions were much wetter than today, particularly during the main LIA phase. Lake Chad, for example, stood some $4 \mathrm{~m}$ above its modern mean from c. $1600 \mathrm{CE}$ to sometime in the $18^{\text {th }}$ century (Maley, 1976). Chronicles of West African empires suggest that drought was rare throughout most of the 1500s through early 1700 s. There are also numerous references to large floods of the Niger, active waterways replacing dry wadis in northern Chad, and a vegetation cover much more verdant than today (Nicholson, 1980). Farther south, at Lakes Tizong and Mbalang in northern Cameroon (Figure 2), a small increase in arboreal pollen may indicate wetter LIA conditions, though the landscape continued to be dominated by the open grasslands established c. 500 CE (Vincens, 2010; 
Nguetsop et al., 2013). At Kajemarum Oasis, the LIA signal is also small. Both Sr/Ca and $\delta^{18} \mathrm{O}$ data indicate that the climate was wetter than during the most extreme phase of drying between C. 500 CE and 1000 and a second period of aridity following the MCA (1250-1450 $\mathrm{CE})$. Overall, however, the proxy data spanning the LIA from this site are variable, with conditions becoming wetter during the initial and later LIA with a drier period c. 1600-1700 CE. Chronological control is insufficient to evaluate the regional synchrony of these shifts (Holmes et al., 1999), but the LIA does not stand out as an exceptionally wet period at this site.

In contrast to the wetter conditions identified in northern subtropical West Africa, there is considerable evidence for a drier climate in the humid West African tropics during the LIA main phase. At Lake Bosumtwi (Figure 2), lacustrine $\delta^{18} \mathrm{O}$ data show a post-MCA return to wet conditions that continued into the early $15^{\text {th }}$ century (Shanahan et al., 2009). This was followed by a period of pronounced drought lasting from c. 1450 CE to 1750 , with dry conditions peaking during the $16^{\text {th }}$ century. Diatom-inferred water depth at Lake Ossa decreased between $1300 \mathrm{CE}$ and 1700, culminating in the lowest levels of the past two millennia (Nguetsop et al., 2010). Further to the south, pollen data from lakes Nguène and Kamelété also indicate more arid conditions from 1550-1700 CE and 1500-1750 CE, respectively (Ngomanda et al., 2007), broadly synchronous with the main-phase LIA drought at Lake Bosumtwi. Documentary evidence also appears to support the timing, within dating precision, of the drought maximum recorded at Lake Bosumtwi. A unique time series of documentary data on drought and disease in coastal Angola spanning 1560 CE to the 1870s based on Portuguese colonial archives (Miller, 1982), suggests that the most calamitous conditions occurred during the 1580s (Verschuren, 2004). Together, these data suggest that in western equatorial Africa the period from c. 1450 CE to 1750 appears to have been the driest of the late Holocene, i.e. at least as dry as the MCA drought.

In eastern Africa (Figure 3), peak MCA drought ended with a return to a moister hydroclimate c. 1200-1250 CE, broadly coeval with the onset of the early-LIA phase. Nile flood levels increased from $1325 \mathrm{CE}$ to 1470 , after which historical records are interrupted (Nicholson, 1980; Fraedrich et al., 1997; Kondrashov et al., 2005). In the central Kenya Rift Valley, abrupt wetland formation at Loboi swamp is dated to 1250 CE (Ashley et al., 2004; Driese et al., 2004). Available high-resolution, well-dated lake-sediment records distributed over the region suggest that, after this common initial stage of post-MCA lake transgression, notable spatial differences developed in the amplitude and timing of LIA hydroclimate variability. In easternmost East Africa, situated eastward of the CAB year-round, relatively humid conditions continued through the main phase of the LIA (Verschuren, 2004). At Lake Naivasha this 500 -year period of relatively moist climate was interrupted by two episodes of lake-level decline in the late- $14^{\text {th }}$ and late- $16^{\text {th }}$ century, respectively (Verschuren et al., 2000; Verschuren, 2001), reflecting multidecadal drought events prominent enough to be recorded 
also in regional vegetation (Lamb et al., 2003). The leaf-wax $\delta D$ time series from Sacred Lake on Mt. Kenya attests to peak pluvial conditions between c. $1700 \mathrm{CE}$ and 1870 (Konecky et al., 2014), but the age control on this record is probably not sufficient to accept this timing with confidence. At Lake Challa, the fairly well-defined post-MCA shift to wetter conditions c. 1300 CE is followed by a period with substantial variability in BIT-index values (Buckles et al., 2016). More sustained high BIT-index values between C. 1570 CE and 1670 suggest that peak LIA humidity in the Lake Challa area was reached c. 50-100 years earlier than at Lake Naivasha. Empirical Orthogonal Function (EOF) analysis of low-pass filtered instrumental rainfall data (Tierney et al., 2013) suggests that the region of eastern Africa that may have experienced a predominantly wet rather than dry climate during the main phase of the LIA extended along the Indian Ocean coast from c. $7^{\circ} \mathrm{S}$ northward to the Horn of Africa, and inland to c. $36^{\circ} \mathrm{E}$ over northern Kenya. This areal delineation of the East African 'Little Ice Age Pluvial' has gained further support from a leaf-wax $\delta \mathrm{D}$ record at $12^{\circ} \mathrm{N}$ in the Gulf of Aden, where wet conditions appear to have peaked in the early $17^{\text {th }}$ century (Tierney et al., 2015).

In westernmost equatorial East Africa, which is more prominently influenced by moisture sourced in the Atlantic Ocean, lake records from western Uganda (Russell and Johnson, 2007; Russell et al., 2007; Mills et al., 2014) and Lake Tanganyika (Cohen et al., 1997; Alin and Cohen, 2003) display a humidity maximum from c. 1200 CE to 1500 , followed by sustained dry conditions during most of the main-phase LIA. The high-resolution \%Mg record from Lake Edward suggests that regional aridity at that time was comparable to that of climax MCA drought (Russell and Johnson, 2007). At this site, LIA drought seems to have already set in by $1450 \mathrm{CE}$. A similar pattern is shown by the 700-year biogenic silica (BSi) record from Lake Malawi (Johnson et al., 2001), where humidity peaked at $1500 \mathrm{CE}$, after which aridification set in, culminating in severe drought around 1800 CE (Crossley et al., 1984; Owen et al., 1990).

Some eastern African lake records present an intermediate temporal pattern between these 'eastern' and 'western' histories, in which climate during the main-phase LIA was drier than during the early LIA, but still wetter than either peak MCA drought or the $20^{\text {th }}$ century average (Figure 3). The most prominent example is Lake Victoria, which according to the diatom-based lake-level reconstruction (Stager et al., 2005) seems to have reached its highest level of the LIA between 1400 CE and 1600, followed by a more modest highstand during the main-phase LIA. Records from Lake Hayq in northern Ethiopia (Lamb et al., 2007) and Lake Bogoria in the Kenya Rift Valley (De Cort et al., 2013) suggest a similar pattern.

In southern Africa (Figure 4), Tyson and Lindsay (1992) and Tyson et al. (2000) found the LIA to be a robust feature in a range of palaeoenvironmental records, and concluded that relatively cool $\left(\sim-1^{\circ} \mathrm{C}\right)$ and dry conditions prevailed over most of the subcontinent during this period. Again, these syntheses rely heavily on speleothem data, with the LIA being identified 
as the period of low $\delta^{18} \mathrm{O}$-inferred temperature at Cango Cave from c. 1100-1900 CE, and relatively depleted $\delta^{18} \mathrm{O}$ at Cold Air Cave from c. 1500-1800 CE.

Links between the summer rainfall zones of northeastern South Africa and Namibia have been proposed (Chase et al., 2010), but signals of moisture availability between these subregions seem to be anti-phased during the MCA and LIA. $\delta^{18} \mathrm{O}$ and growth-rate records from speleothems at Dante's Cave (Sletten et al., 2013) and the $\delta^{15} \mathrm{~N}$ record from rock-hyrax middens at Spitzkoppe (Chase et al., 2009) indicate that the early LIA was characterised by variable/generally drier conditions relative to the MCA, followed by a rapid transition to more humid conditions from c. 1600-1850 CE (Figure 4). In the eastern summer rainfall zone, climate reconstructions derived from the Wonderkrater pollen sequence indicate cooler, drier conditions c. 1400-1800 CE (Scott, 1982; Thackeray, 1999; Truc et al., 2013). However, the resolution and chronological control of this sequence is too low to elucidate the precise nature of hydroclimatic change. Better resolved $\delta^{13} \mathrm{C}$ records from the Pafuri baobabs (Woodborne et al., 2015) and Cold Air Cave speleothems (Lee-Thorp et al., 2001; Holmgren et al., 2003) indicate relatively humid conditions during the early LIA, followed by marked aridification from c. $1600-1800 \mathrm{CE}$

Evidence provided by shell middens and marine cores from the west coast of southern Africa suggests that south Atlantic SSTs were lower than today during the LIA. However, the low resolution of these records makes identification of the LIA as a discrete period difficult. At Elands Bay, a SST depression is seen to have existed from c. 1300-1580 CE, but as pre-LIA temperatures between $0 \mathrm{CE}$ and 1300 are constrained by only a single data point, the context for this apparent anomaly is unclear (Cohen et al., 1992). Farmer et al. (2005) obtained a more complete record of SSTs and upwelling activity along the west coast of Namibia from marine core ODP 1084b. In it, more intense upwelling appears to have occurred from c. 1050-1500 CE, corresponding broadly with a period of reduced SSTs from 950-1600 CE. While neither can be said to represent a distinct manifestation of the LIA, the terrestrial records from Namibia noted above, register similar fluctuations, particularly a marked shift c. $1500 \mathrm{CE}$, suggesting either a causal link or a shared response between coastal upwelling and regional climates.

Regional reviews for southern Africa have proposed an inverse relationship in hydroclimate trends between its summer and winter rainfall zones (Tyson and Lindesay, 1992; Tyson et al., 2000; Chase and Meadows, 2007). Diatom data from Verlorenvlei in the southwestern Cape indicate increasing precipitation following the MCA, potentially linked to equatorward shifts of the westerly storm tracks (Stager et al., 2012). Stable isotope records on rock-hyrax middens from Seweweekspoort, southern Cape, indicate a period of generally wetter conditions during the LIA, but not significantly different from the MCA, and more clearly part of a general longterm increase in humidity (Chase et al., 2013). 


\subsection{The end of the LIA (1750-1850 CE)}

During the last century of the LIA, palaeoenvironmental records from lakes, speleothems and other natural archives start to be supplemented by documentary evidence (e.g. Nicholson, 1981; Vogel, 1989; Nicholson, 2000; Nash and Endfield, 2002a, 2002b; Kelso and Vogel, 2007; Nash and Endfield, 2008; Nash and Grab, 2010; Norrgård, 2015; Nash et al., 2016), tree-ring records (e.g. Dunwiddie and LaMarche, 1980; Therrell et al., 2006; Woodborne et al., 2015), reconstructions from ships' logbooks (Hannaford et al., 2015) and, from a handful of countries, early rain-gauge data (Nicholson et al., 2012a; Nicholson et al., 2012b). The most detailed historical evidence for the late $18^{\text {th }}$ century comes from West Africa. Here, documents suggest that the Sahel, especially around the Niger Bend close to Timbuktu, and inland areas of the Guinea coast, experienced successive droughts from the late 1730s to the mid-1750s (Nicholson, 1980, 1996; Nicholson et al., 2012a; Norrgård, 2015). Annually-resolved records from 1750 onwards indicate that these regions then experienced alternating wetter (1757-65, 1781-88) and drier (1765-80, 1789-98) decadal-scale periods (Norrgård, 2015). Conditions at the Guinea coast appear to have been, at times, in antiphase with those of the Sahel, with wetter conditions extending from 1750-77 and 1788-98 and drier from 1777-87 (Norrgård, 2015). Records from the late $18^{\text {th }}$ century are also available for southwest Africa. Around Luanda on the Atlantic coast, the 1780 s and 1790s appear to have been among the driest decades since $1560 \mathrm{CE}$, second only to the 1580s (Miller, 1982).

Historical records are relatively sparse for the early $19^{\text {th }}$ century. The first decade appears to have been dry over much of the African continent, although there are some discrepancies between documentary and other proxy data where these are available (Hannaford and Nash, 2016). For example, while the documentary record of Nicholson et al. (2012a) suggests protracted drought across southern Africa from 1800-1811, tree-ring series for Zimbabwe (Therrell et al., 2006) and meteorological observations carried out on European trading ships passing by South Africa (Hannaford et al., 2015) for the same period, suggest wetter episodes alternating with drought.

The most notable event identified from historical sources was a near-continent wide episode of below-average rainfall that prevailed throughout much of the $1820 \mathrm{~s}$ and $1830 \mathrm{~s}$ (Nicholson et al., 2012a) (Figure 5). This appears to have been the culmination of a drying trend that began in the late $18^{\text {th }}$ century, possibly during the mid-1780s (Nicholson, 1996) or slightly later in coastal West Africa (Norrgard, 2015). Ships' logbook-based reconstructions for KwaZulu-Natal (Hannaford et al., 2015), and documentary records for the Kalahari (Nash and Endfield, 2002a), Namaqualand (Kelso and Vogel, 2007) and the Eastern Cape (Vogel, 1989), all suggest reduced austral summer rainy season precipitation over southern Africa during these decades. Elsewhere, drought conditions were evident across the entire Sahel, all the way westward to the Cape Verde Islands, where some $40 \%$ of the population reportedly 
perished in 1830 alone (Brooks, 2006). Severe drought struck Ethiopia in 1828-1829 CE (Wolde-Georgis, 1997), while a disastrous famine dated to the 1830s in eastern Africa (Hartwig, 1979) resulted in massive population migrations. According to Burton (1860), famine and drought prevailed in the Pangani Valley, Tanzania, for roughly two decades in the 1820s and 1830s. Krapf (1860) described a similar situation in Mombasa, Kenya. Water levels of Lake Tanganyika and Lake Rukwa, as deduced from historical and geographical information, were low during the late $18^{\text {th }}$ and early $19^{\text {th }}$ centuries until the 1840 s (Nicholson, 1999). Assuming that the drying trend in eastern Africa commenced around $1785 \mathrm{CE}$, Nicholson and Yin (2001) used a water-balance model calibrated with gauge data to estimate that rainfall in the Lake Victoria catchment between $1785 \mathrm{CE}$ and 1835 was roughly $13 \%$ below the $20^{\text {th }}$ century mean.

In broad agreement with these historical data, the majority of well-resolved palaeoclimate records for eastern Africa (Figure 3) show that the main-phase LIA ended in an episode of aridity dated to the late 1700 s and early 1800s. At Lake Challa, where this episode is well constrained chronologically, the period 1780-1820 CE was the most arid since the MCA (Buckles et al., 2016). In the Lake Victoria region it appears to have been the driest period of the last millennium (Stager et al., 2005), i.e. drier than the MCA. Severe aridity between 1750 CE and 1830 has also been inferred for the Lake Baringo area in central Kenya by Kiage and Liu (2009) on the basis of pollen and fungal spores. Using records from Lake Baringo and two shallow crater lakes in western Uganda, Bessems et al. (2008) showed that this widespread drought temporarily overrode the east-west contrast in moisture patterns across the $C A B$, as had partly also been the case during the MCA. Although the lake transgression following this drought in the 1820s-1830s was a widespread phenomenon across eastern Africa, its amplitude remained relatively modest. Many lakes both in western Uganda and the Kenya Rift Valley were shallower than today and either swampy or more saline (Verschuren, 1999a, 1999b; Bessems et al., 2008).

The combined evidence suggests that average mid-19 ${ }^{\text {th }}$ century climate conditions remained relatively dry for eastern Africa, and that the $19^{\text {th }}$ century was drier, on average, than the $20^{\text {th }}$ century. In contrast, multiproxy reconstructions for the southern African summer rainfall zone indicate that the $19^{\text {th }}$ century was significantly wetter than the $20^{\text {th }}$ (Neukom et al., 2014; Nash et al., 2016).

\subsection{The Early Modern Period (1850 - 1950 CE)}

Evidence for spatial hydroclimate variability across Africa during the early modern period comes from a combination of natural proxies, documentary evidence and rain-gauge data. The gauge data for this period are summarized in Figure 6. In North Africa, pollen data from Lake Yoa suggest drying in the central Sahara from the mid-19 ${ }^{\text {th }}$ century $(1840$ s) onwards 
(Lézine et al., 2011a). The northwest coastal zone became notably drier around the 1860s but very wet conditions prevailed in the 1890s (Nicholson et al., 2012a). The Sahel became markedly wetter around 1850 and, with the exception of drought in the 1910s, remained so through to the end of this period. Maximum rainfall appears to have occurred in the 1880s in the Sahel and regions to the north of it, although a handful of very wet years occurred in the 1870s. Rainfall along the Guinea coast showed little change from the earlier $19^{\text {th }}$ century; the most notable occurrences were prolonged dry intervals in the 1860 s and 1870s.

Following extreme early-19 ${ }^{\text {th }}$ century drought (see above), eastern Africa had become wetter in the 1840s but in the 1850s-1860s rainfall was near, rather than above, average (Nicholson et al., 2012a), and multiple evidence points to a new severe drought event in the final decades of the $19^{\text {th }}$ century. In the central Kenya Rift Valley, very low water levels and/or elevated salinity is dated to between $1870 \mathrm{CE}$ and the early 1890s (Verschuren et al., 1999b; Verschuren et al., 1999a; Verschuren, 1999a, 1999b). The shallow and endorheic lakes Nakuru and Elementeita stood completely dry (De Cort et al., 2013). In Ethiopia, major late$19^{\text {th }}$ century drought is recorded in the sediments of Lake Abiyata (Legesse et al., 2002), and in a Juniperus procera tree ring record from the Northern Gondar area (Wils et al., 2010), and is associated with one of the most severe famines of the last few centuries (Pankhurst, 1966). This "Great Ethiopian Famine" (1888-1892 CE) is said to have cost the lives of one third of the country's population. In northern Tanzania, as much as $40-75 \%$ of pastoralist Maasai may have succumbed (lliffe, 1987). Lake Tanganyika's level also dropped suddenly during this period (Nicholson, 1999). Growth rate and $\delta^{18} \mathrm{O}$ signals of speleothems from the Mechara caves, southeastern Ethiopia, indicate that extended dry spells continued into the first half of the $20^{\text {th }}$ century (Baker et al., 2007).

Fragmentary historical information on the level of Lake Naivasha since the 1880 s shows a major transgression from 1880 onwards, reaching the historically highest recorded level between 1890 and 1900 (Åse et al., 1986). In a palaeohydrological analysis of Lake Turkana, Bloszies and Forman (2015) first calibrated the relationship between the lake's surface level and western Indian and eastern Atlantic SSTs for the period 1992-2013 CE, and then used historical SST records to infer Turkana lake levels back to $1857 \mathrm{CE}$, thus supplementing the discontinuous $20^{\text {th }}$ century observational record. Consistent with earlier work (Williams et al., 2012), the results suggest a decreasing contribution of Atlantic-derived moisture to eastern African precipitation over the $20^{\text {th }}$ century.

In southern Africa, the end of the early $19^{\text {th }}$ century arid interval was spatially variable. Documentary and rain-gauge data suggest that very dry years prevailed in south-central regions until the 1890s (Nicholson et al., 2012a). South of c. $15^{\circ} \mathrm{S}$, however, multiproxy reconstructions for the summer rainfall zone reveal the early 1860 s to be the driest period of the $19^{\text {th }}$ century, and the 1870 s, 1880s and early-mid 1890s the wettest decades of the last 
200 years (Neukom et al., 2014; Nash et al., 2016). In the winter rainfall zone of southwest South Africa, relatively dry conditions prevailed during the $19^{\text {th }}$ century, particularly in the 1860 s and 1870 s. Wetter conditions were particularly prevalent in the early $20^{\text {th }}$ century, the 1950s, 1980s and 1990s, but a long sequence of dry years occurred in the 1920s and 1930s (Vogel, 1989; Nicholson et al., 2012a; Neukom et al., 2014).

A number of the longer records discussed earlier also include this early modern period. Lake Bosumtwi (Shanahan et al., 2009), Lake Edward (Russell et al., 2007), Lake Naivasha (Verschuren et al., 2000) and Spitzkoppe (Chase et al., 2009) all show a mid-19 ${ }^{\text {th }}$-century period of modest wetness (or relative aridity) followed by much wetter conditions from the 1880 s until the 1920s or 1930s, and a general drying trend from then until the 1950s (Figures 2-4). Uncertainty in dating of those records lacking historical counterparts limits our ability to make even decadal-scale correlations, but pattern similarities between them are highly suggestive of a pan-African coherence.

\subsection{The period of recent warming (1950 - 2015 CE)}

The most recent era has been characterised by several continent-wide episodes of anomalous rainfall relative to the long-term average, each lasting a decade or longer (Nicholson, 2001). Rainfall during the 1950s was well above average throughout the subtropics of both hemispheres, but the equatorial latitudes were comparatively dry. The inverse of this pattern prevailed during the 1960s, with exceptional rainfall in 1961 (Conway, 2002) leading to peak river discharge and peak levels for Lake Albert (Sutcliffe and Parks, 1999), Lake Victoria (Sene and Plinston, 1994), Lake Naivasha (Åse et al., 1986) and Lake Tanganyika (Nicholson, 1999) in 1963-1964. This equatorial humid anomaly extended to the southern Sahel, where rainfall remained above normal until the later 1960s. The 1970s were dry throughout most of the continent, but particularly so in the Sahel. In contrast, a series of wet years prevailed in parts of southern Africa during the mid- to late-1970s (Nicholson, 2001). The 1980s was a decade of continent-wide aridity (Nicholson, 2001) (Figure 5), with 1983 the driest of the last 200 years across the southern African summer rainfall zone (Neukom et al., 2014). Exceptions were parts of the northern and southern mid-latitude extremes and isolated sectors of eastern Africa, particularly the highlands. Arid conditions continued throughout most of the 1990s, except in much of eastern Africa and in the winter rainfall zone of South Africa (Nicholson, 2001).

During the period 1950-present, the most extreme conditions occurred in the Sahel, which suffered three decades of drought spanning 1968-1997 (Nicholson, 2001). At least partial recovery occurred early in the $21^{\text {st }}$ century. In other parts of Africa, some very extreme years occurred between 1950 and the present time (Kijazi and Reason, 2009; Hastenrath et al., 
2010). The mid-1970s included some of the wettest years on record for parts of southern Africa, particularly 1974 and 1976.

Hulme et al. (2001) evaluated a subset of African rainfall records for 1901-1995, and found that, except over the highlands of Sierra Leone and Cameroon and in a few areas of southern equatorial Africa, the trend throughout the continent over the course of the $20^{\text {th }}$ century was less than $10 \%$ of the annual mean. However, clear trends emerge since the 1960 s, with rainfall increasing in equatorial regions and decreasing in the subtropics of both hemispheres. Between 1960-1989 and 2000-2009, mean March-June and July-September rainfall in the western Sahel decreased by $20-40 \mathrm{~mm}$ per decade (Funk et al., 2012). Mean annual rainfall increased marginally in the central Sahel over the same time period, with a strong increase during both seasons over Ethiopia and western Kenya. Climate modelling shows a link between high SSTs in the western Indian Ocean and enhanced precipitation over eastern Africa during the short rains (Ummenhofer et al., 2009). Consequently, Shongwe et al. (2011) projected that excessive OND rainfall will drive an overall increase in mean precipitation as a consequence of anthropogenic warming. Since then, Liebmann et al. (2014) have demonstrated that such an increase in OND rainfall is already occurring. Williams and Funk (2011), however, report a contrasting long-term decrease in the quantity of long (MAM) rains over eastern Kenya and the eastern flank of the Ethiopian highlands during broadly the same time period (1979-2009). These authors point to a strong warming of the Indian Ocean and consequent suppression of convection over eastern equatorial Africa as the main drivers. This drying trend, during the main crop-growing season, is observed all along the western rim of the Indian Ocean, and in eastern portions of the Congo Basin (Zhou et al., 2014), and could be problematic given the importance of rain-fed agriculture in the region (Funk et al., 2008). Lyon and DeWitt (2012) suggest that this decline in the long rains started more recently, and abruptly, around 1999. At the other end of the spectrum, Tierney et al. (2015) suggest, on the basis of progressively increasing leaf-wax $\delta D$ values in Gulf of Aden sediments, that the long rains in the eastern Horn of Africa region have been declining more or less continuously since the mid-19th century onwards, and that the current (more specifically, end-20 $0^{\text {th }}$ century) regional climate approaches the driest conditions recorded in the past 2000 years. On the whole, these seasonally contrasting and variably timed trends in rainfall amount demonstrate the necessity of an improved understanding of eastern African climate dynamics.

During the last 10-15 years, a number of extreme events have occurred. While the Sahel has partially recovered from drought during the 1970 s and 1980s, rainfall has recently been highly variable, and generally remained below the 1920-2003 average. In the far eastern Sahel and eastern Africa, drought appears to have become more frequent and more intense (Funk et al., 2013; Hoell and Funk, 2014; Nicholson, 2014a). During the years 2008-2011, rainfall was $30-75 \%$ below average over the Horn of Africa, Kenya and most of the Sudan. Between 
July 2010 and June 2011 the situation was even more severe, with rainfall being at least 50$75 \%$ below average over nearly half of the drought-stricken region (Nicholson, 2014a). Southern Africa was affected by severe drought in 2007 and 2011, but, in regions such as Namibia and Botswana, a considerable rainfall increase and landscape greening occurred in the intervening years (Stockhall, 2010). Following the 2008-11 drought in eastern Africa, Kenya has seen a spectacular transgression of its Rift Valley lakes. By September 2013, lakes Naivasha, Nakuru and Bogoria had risen significantly, while Lake Baringo had reached levels not experienced since (at least) the early 1900s (Onywere et al., 2013).

These examples appear to be part of a general trend towards increased interannual variability of rainfall over several regions. In the Sahel and in eastern Africa, drought years have been interspersed with extreme floods. Droughts occurred in eastern Africa in 2005, followed by floods in 2006 (Hastenrath et al., 2007; Kijazi and Reason, 2009; Hastenrath et al., 2010). An extreme shift between drought and flood also occurred in November of 2010 and 2011, leading to the above-mentioned lake transgressions. In the Sahel, below-average rainfall prevailed during most of the period 1968 to 2013, yet 1994 and 1999 were some of the wettest years on record. The impacts of the strong 2015-16 El Niño upon rainfall across the African continent are yet to be fully understood, although the associated droughts in southern Africa and the Horn of Africa were the most severe in decades.

\section{Discussion}

Several obstacles, including patchy geographical coverage, low data resolution and high chronological uncertainty of available records, complicate the construction of a complete picture of African hydroclimate history for the past 2000 years. When dealing with natural archives of environmental change, any climatic interpretation should take into account climateto-proxy control, which is not always unambiguous and archive-dependent.

\subsection{Drivers of past hydroclimate variability}

The data synthesis presented in this paper allows the recognition of some general, broadscale patterns of hydroclimatic variability. Overall, Africa's moisture balance history contains marked differences within and between regions, combined with large-scale climate changes that are (nearly) uniform across the continent (Figures 7 and 8). Obvious candidates to explain decadal- to century-scale interregional precipitation differences are fluctuations in the position and intensity of the tropical rainfall belts, and their variable extension away from the equator during Northern or Southern Hemisphere summer (Schneider et al., 2014). Moisture balance patterns during the first millennium CE inferred from tropical and subtropical West Africa support this suggestion. As noted in section 4.1, records from the northern portion of equatorial West Africa (e.g. Kajemarum Oasis, lakes Tizong, Bambili and Bosumtwi; Figure 2), spanning 
a north-south transect from Nigeria to Cameroon, indicate wetter conditions overall during the first half of the first millennium CE than during the second. In some series, this is manifested as an abrupt aridification centred around $500 \mathrm{CE}$, while in others the changes are more gradual. This pattern shows up in both pollen and hydrological records, making it more likely that the vegetation change is related to changes in climate as opposed to land use. The strength of the signal also appears to decrease toward the equator, though this may be in part a reflection of proxy sensitivity. Available data suggest that Northern Hemisphere aridification from c. 500 CE to 1000 may have been accompanied by a shift to more humid conditions in the southern equatorial latitudes (Figure 7), indicated by lake records from Gabon and the Congo (lakes Nguène, Kamalété, Sinnda; Figure 2). These opposing north-south precipitation changes are consistent with a southward shift in the tropical rain belt over Africa, which would have reduced the length of the rainy season in the north while increasing it in the south.

A prominent feature of the main-phase LIA period in Africa is the trend towards declining rainfall at tropical sites under an Atlantic Ocean regime. This pattern extends eastwards as far as western portions of the East African plateau, exemplified by the records of Lake Edward and nearby crater lakes (Russell and Johnson, 2007; Russell et al., 2007; Verschuren and Charman, 2008; Figure 3). Russell and Johnson (2007) postulated that a southward shift of the ITCZ might be responsible for the decline, but this is inconsistent with the wetter conditions that prevailed in the Sahel at the same time.

An equally notable feature is the resulting spatial dichotomy of a drier main-phase LIA in tropical West and Central Africa, contrasting with a wetter easternmost East Africa (Verschuren, 2004). Focussing on the seven available 1000-year hydroclimate records from eastern Africa with sufficient time control, Tierney et al. (2013) demonstrated that the antiphase variation between sites close to the Indian Ocean and those of the Albertine Rift Valley is driven mainly by temporal variations in the SST gradient across the Indian Ocean. An influence of El Niño variability in the creation of this spatial pattern, as suggested by Russell and Johnson (2007), is not inconsistent with this mechanism.

The CAB also appears to have played an important role in LIA climate, with studies inferring either a westward shift (Russell and Johnson, 2007), or weakened convergence (Tierney et al., 2011a), during the main-phase LIA. The hydrology of lake basins located beneath the convergence zone during at least part of the year, and which are thus under the influence of both Atlantic and Indian Ocean regimes, can be expected to display an intermediate pattern of climate anomalies. Evidence suggests that during the later stages of the LIA, the influence of the Indian Ocean at sites including Lake Victoria (Stager et al., 2005), Lake Bogoria (De Cort et al., 2013) and Lake Hayq (Lamb et al., 2007) (Figure 3), was counteracted by a weaker Atlantic monsoon, damping the effects of maximum ENSO-related precipitation. 
The scenario of a westward migration of the CAB during the LIA may also explain the patterns observed at a set of sites in southern Africa (Figure 7). Meteorologically speaking, this migration would most likely translate into displacements and changes in the relative intensity of the Walker cells over the Atlantic and Indian Oceans. The records from Dante's Cave $\left(\delta^{18} \mathrm{O}\right)$ and Spitzkoppe $\left(\delta^{15} \mathrm{~N}\right)$, for example, all evolve from a humidity minimum at the start of the LIA to a maximum during the early $18^{\text {th }}$ century, i.e. generally similar to the LIA pattern seen in easternmost East Africa (Figure 4). These sites are today located close to or west of the $C A B$ during the time of the year in which they receive most precipitation. Their general consistency with the rainfall trends of eastern East Africa during the last millennium may, therefore, suggest a weaker Atlantic-sourced African monsoon during the main-phase LIA - this would have resulted in an overall westward shift in the mean longitudinal position of the $C A B$, and increasing Indian Ocean dominance over rainfall variability in the western part of southern Africa. At the same time, drying of sites over the course of the LIA in southeastern tropical Africa (e.g. Lake Malawi) and further south (Wonderkrater, Pafuri, Cold Air Cave; Figure 4) suggests accentuation of El Niño-like spatial variability, since this larger region tends to be drought-prone during El Niño phases (Lindesay et al., 1986; Camberlin et al., 2001), in contrast with the higher rainfall brought to equatorial eastern Africa.

By employing principal component analysis on an extensive set of historical precipitation data covering the $19^{\text {th }}$ and $20^{\text {th }}$ centuries, Nicholson (2014b) identified a limited number of continental-scale patterns that have dominated spatial rainfall variability on the inter-annual timescale. The study demonstrates that the most common modes are: (1) anomalies of the same sign over most of the continent, (2) contrasting anomalies between the low latitudes and the subtropics, and (3) an east-west opposition in the equatorial region and southern Africa. The stability of these patterns over the past 200 years strongly suggests that they constitute inherent attributes of rainfall variability over Africa. Within these modes, the shift between opposing poles can occur over small spatial scales, which has important implications for the interpretation of palaeoclimate archives that are situated at or close to these transition areas. In principle, the palaeoclimate record should allow us to consider whether the relative dominance of these main types of hydroclimate variability, appearing stable throughout the past 200 years, changed over longer time periods. For instance, the widespread drought of the late- $18^{\text {th }}$ to early- $19^{\text {th }}$ century is an example of a prolonged continent-wide, in-phase climate anomaly. In contrast, the LIA epoch has strong parallels with the third mode, i.e. an equatorial east-west out-of-phase pattern that was also found to explain a significant part of the interannual variability in the historical period. The preceding MCA bears similarities to the second mode stated above, with drought throughout both the Indian and Atlantic domains of eastern Africa contrasting with wetter conditions in the Sahel and southern Africa. However, significant differences are also observed, as the arid signal is not manifested in West African lake records south of the equator. This sequence of shifting interregional moisture-balance 
relationships suggests that the mutual dominance of these common modes of continental rainfall variability may change over time. So far, the link to large-scale phenomena (e.g. SST and atmospheric factors) has not been investigated, therefore their balance remains poorly understood. Looking further into this would be an example of how the study of historical records and longer natural archives could greatly complement each other.

\subsection{Directions for future research}

The preceding discussion has highlighted a number of geographical and temporal gaps in our understanding of the evolution of African hydroclimates over the last 2000 years, together with some potential avenues for future research. First, the palaeoclimate community should concentrate on improving the spatial coverage of high-resolution, (semi-) quantitative reconstructions of moisture balance records, to capture not only inter-regional differences but also sub-regional patterns. For example, the limited number of high-quality records from the first millennium CE impedes testing of whether the spatial patterns in hydroclimate documented for the LIA were unique. More and longer archives are needed to robustly integrate low-latitude African hydroclimate variability into global patterns of climate history.

Future efforts should also focus on improving our understanding of the interactions between the main circulation systems - plus oceanic-mode variability and other aspects of global climate dynamics - affecting Africa. Much is already known from contemporary climatology about the role of SSTs as drivers of rainfall across the continent (e.g. Goddard and Graham, 1999; Reason and Jagadheesha, 2005), including during El Niño and La Niña phases (e.g. Nicholson and Kim, 1997; Nicholson and Selato, 2000). However, aspects of large-scale atmospheric circulation generally considered by palaeoclimatologists, such as the major convergence zones or links to ENSO, do not suffice to explain all patterns of hydroclimate variability that occurred during the last 2000 years. Complex, regional-scale mechanisms can significantly interact with large-scale atmospheric and oceanic drivers of precipitation, counteracting them in some regions. As an example, some systems that are not primary mechanisms of precipitation, like the diagonal troughs that impact both northern and southern Africa, might have played a much greater role in the past (Nicholson, 1980).

Historical climatologists could usefully work to address gaps in the Africa-wide rainfall reconstruction compiled by Nicholson et al. (2012a); these are most notable in equatorial and more arid areas (Nash and Adamson, 2014). Clearly, progress will be dependent upon the availability of historical sources, but it should be possible to achieve similar temporal resolution for the $19^{\text {th }}$ century in eastern Africa and coastal West Africa to that already available for southern Africa. Major collections of French, German, English, Portuguese and Arabic language, and in the case of Ethiopia, local Geez and Amharic, documents remain largely unexplored for their climate reconstruction potential. The analysis of Arabic-language 
manuscripts in various cities across the Sahel, for example, would permit the reconstruction of long-term rainfall variability along the southern margin of the Sahara, and bridge the gap between lake sediment and instrumental records (Nash and Adamson, 2014). Importantly, however, any improved knowledge of past climate change should be translated into an understanding of current climate patterns and expectations for the future.

\section{Acknowledgements}

The authors thank the PAGES Scientific Steering Committee for their continuing support of the Africa 2k Working Group, and the two reviewers for their helpful comments. Thanks also to Doug Klotter for assistance with the compilation of Figures 5 and 6. DJN's involvement in this synthesis was in part supported by Leverhulme Trust Research Project Grant F/00 504/D. GDC and DV acknowledge support from the Belgian Federal Science Policy through the BRAIN-be project BR/121/A2 'PAMEXEA'. BMC's involvement was supported in part by the European Research Council (ERC) under the European Union's Seventh Framework Programme (FP7/2007e2013)/ERC Starting Grant "HYRAX", grant agreement no. 258657. SEN was supported by NSF grants AGS 1160750 and AGS 1445605. 


\section{References}

Alin, S.R., Cohen, A.S., 2003. Lake-level history of Lake Tanganyika, East Africa, for the past 2500 years based on ostracode-inferred water-depth reconstruction. Palaeogeography, Palaeoclimatology, Palaeoecology 199, 31-49.

Åse, L.E., Sernbo, K., Syren, P., 1986. Studies of Lake Naivasha, Kenya and its drainage area. Institute of Physical Geography, Stockholm University.

Ashley, G.M., Maitima Mworia, J., Muasya, A.M., Owen, R.B., Driese, S.G., Hover, V.C., Renaut, R.W., Goman, M.F., Mathai, S., Blatt, S.H., 2004. Sedimentation and recent history of a freshwater wetland in a semi-arid environment: Loboi Swamp, Kenya, East Africa. Sedimentology 51, 1301-1321.

Asrat, A., Baker, A., Umer, M., Moss, J., Leng, M., van Calstren, P., Smith, C., 2007. A highresolution multi-proxy stalagmite record from Mechara, Southeastern Ethiopia: Paleohydrological implications for speleothem paleoclimate reconstruction. Journal of Quaternary Science 22, 53-63.

Bader, J., Latif, M., 2003. The impact of decadal-scale Indian Ocean sea surface temperature anomalies on Sahelian rainfall and the North Atlantic Oscillation. Geophysical Research Letters 30, doi: 10.1029/2003gl018426.

Baker, A., Asrat, A., Fairchild, I.J., Leng, M.J., Wynn, P.M., Bryant, C., Genty, D., Umer, M., 2007. Analysis of the climate signal contained within $\delta^{18} \mathrm{O}$ and growth rate parameters in two Ethiopian stalagmites. Geochimica Et Cosmochimica Acta 71, 2975-2988.

Barker, P., Telford, R., Gasse, F., Thevenon, F., 2002. Late Pleistocene and Holocene palaeohydrology of Lake Rukwa, Tanzania, inferred from diatom analysis. Palaeogeography Palaeoclimatology Palaeoecology 187, 295-305.

Bertaux, J., Schwartz, D., Vincens, A., Sifeddine, A., Elenga, H., Mansour, M., Mariotti, A., Fournier, M., Martin, L., Wirrmann, D., Servant, M., 2000. Enregistrement de la phase sèche d'Afrique Centrale vers 3000 ans BP par la spectrométrie IR dans les lacs Sinnda et Kitina (Sud-Congo), in: Servant, M., Servant-Vildary, S. (Eds.), Dynamique à long terme des écosystèmes forestiers intertropicaux. IRD/UNESCO/MAB/CNRS, Paris, pp. 43-49.

Bessems, I., Verschuren, D., Russell, J.M., Hus, J., Mees, F., Cumming, B.F., 2008. Palaeolimnological evidence for widespread late 18th century drought across equatorial East Africa. Palaeogeography, Palaeoclimatology, Palaeoecology 259, 107-120.

Blaauw, M., van Geel, B., Kristen, I., Plessen, B., Lyaruu, A., Engstrom, D.R., van der Plicht, J., Verschuren, D., 2011. High-resolution 14C dating of a 25,000-year lake-sediment record from equatorial East Africa. Quaternary Science Reviews 30, 3043-3059.

Blamey, R.C., Reason, C.J.C., 2013. The Role of Mesoscale Convective Complexes in Southern Africa Summer Rainfall. Journal of Climate 26, 1654-1668.

Bloszies, C., Forman, S.L., 2015. Potential relation between equatorial sea surface temperatures and historic water level variability for Lake Turkana, Kenya. Journal of Hydrology 520, 489-501.

Braconnot, P., Joussaume, S., de Noblet, N., Ramstein, G., 2000. Mid-Holocene and Last Glacial Maximum African monsoon changes as simulated within the Paleoclimate Modelling Intercomparison Project. Global and Planetary Change 26, 51-66.

Brooks, G.E., 2006. Cabo Verde: Gulag of the South Atlantic: Racism, fishing prohibitions, and famines. History in Africa 33, 101-135.

Buckles, L.K., Weijers, J.W.H., Verschuren, D., Cocquyt, C., Sinninghe Damsté, J.S., 2016. Short-term variability in the sedimentary BIT index of Lake Challa, East Africa over the past 2200 years: validating the precipitation proxy. Climate of the Past 12, 1243-1262.

Burton, R.F., 1860. The Lake Regions of Central Africa, A Picture of Exploration. Longman, Green, Longman and Roberts, London.

Camberlin, P., Janicot, S., Poccard, I., 2001. Seasonality and atmospheric dynamics of the teleconnection between African rainfall and tropical sea-surface temperature: Atlantic vs. ENSO. International Journal of Climatology 21, 973-1005.

Castaneda, I.S., Werne, J.P., Johnson, T.C., 2007. Wet and arid phases in the southeast African tropics since the Last Glacial Maximum. Geology 35, 823-826. 
Chase, B.M., Meadows, M.E., 2007. Late Quaternary dynamics of southern Africa's winter rainfall zone. Earth-Science Reviews 84, 103-138.

Chase, B.M., Meadows, M.E., Carr, A.S., Reimer, P.J., 2010. Evidence for progressive Holocene aridification in southern Africa recorded in Namibian hyrax middens: implications for African Monsoon dynamics and the "African Humid Period". Quaternary Research 74, 36-45.

Chase, B.M., Boom, A., Carr, A.S., Meadows, M.E., Reimer, P.J., 2013. Holocene climate change in southernmost South Africa: rock hyrax middens record shifts in the southern westerlies. Quaternary Science Reviews 82, 199-205.

Chase, B.M., Meadows, M.E., Scott, L., Thomas, D.S.G., Marais, E., Sealy, J., Reimer, P.J., 2009. A record of rapid Holocene climate change preserved in hyrax middens from southwestern Africa. Geology 37, 703-706.

Chase, B.M., Lim, S., Chevalier, M., Boom, A., Carr, A.S., Meadows, M.E., Reimer, P.J., 2015. Influence of tropical easterlies in southern Africa's winter rainfall zone during the Holocene. Quaternary Science Reviews 107, 138-148.

Chase, B.M., Scott, L., Meadows, M.E., Gil-Romera, G., Boom, A., Carr, A.S., Reimer, P.J., Truc, L., Valsecchi, V., Quick, L.J., 2012. Rock hyrax middens: a palaeoenvironmental archive for southern African drylands. Quaternary Science Reviews 56, 107-125.

Chevalier, M., Chase, B.M., 2015. Southeast African records reveal a coherent shift from high- to low-latitude forcing mechanisms along the east African margin across last glacial-interglacial transition. Quaternary Science Reviews 125, 117-130.

Claussen, M., Kubatzki, C., Brovkin, V., Ganopolski, A., Hoelzmann, P., Pachur, H.J., 1999. Simulation of an abrupt change in Saharan vegetation in the mid-Holocene. Geophysical Research Letters 26, 2037-2040.

Cockcroft, M.J., Wilkinson, M.J., Tyson, P.D., 1987. The application of a present-day climatic model to the late Quaternary in southern Africa. Climatic Change 10, 161-181.

Cohen, A.L., Parkington, J.E., Brundrit, G.B., van der Merwe, N.J., 1992. A Holocene marine climate record in mollusc shells from the Southwest African coast. Quaternary Research 38, 379-385.

Cohen, A.S., Talbot, M.R., Awramik, S.M., Dettman, D.L., Abell, P., 1997. Lake level and paleoenvironmental history of Lake Tanganyika, Africa, as inferred from late Holocene and modern stromatolites. Geological Society of America Bulletin 109, 444-460.

Collins, J.A., Schefuß, E., Heslop, D., Mulitza, S., Prange, M., Zabel, M., Tjallingii, R., Dokken, T.M., Huang, E., Mackensen, A., Schulz, M., Tian, J., Zarriess, M., Wefer, G., 2011. Interhemispheric symmetry of the tropical African rainbelt over the past 23,000 years. Nature Geoscience 4, 42-45.

Conway, D., 2002. Extreme rainfall events and lake level changes in East Africa: Recent events and historical precedents, in: Odada, E.O., Olago, D.O. (Eds.), East African Great Lakes: Limnology, Palaeolimnology and Biodiversity. Kluwer Academic, pp. 63-92.

Cremaschi, M., Pelfini, M., Santilli, M., 2006. Cupressus dupreziana: a dendroclimatic record for the middle-late Holocene in the central Sahara. The Holocene 16, 293-303.

Crossley, R., Davison-Hirschmann, S., Owen, R.B., Shaw, P., 1984. Lake level fluctuations during the last 2000 years in Malawi, in: Vogel, J.C. (Ed.), Late Cainozoic palaeoenvironments of the southern hemisphere. Balkema, Rotterdam, pp. 305-316.

De Cort, G., Bessems, I., Keppens, E., Mees, F., Cumming, B., Verschuren, D., 2013. LateHolocene and recent hydroclimatic variability in the central Kenya Rift Valley: The sediment record of hypersaline lakes Bogoria, Nakuru and Elementeita. Palaeogeography, Palaeoclimatology, Palaeoecology 388, 69-80.

deMenocal, P., Ortiz, J., Guilderson, T., Adkins, J., Sarnthein, M., Baker, L., Yarusinsky, M., 2000. Abrupt onset and termination of the African Humid Period: rapid climate responses to gradual insolation forcing. Quaternary Science Reviews 19, 347-361.

Driese, S.G., Ashley, G.M., Li, Z.-H., Hover, V.C., Owen, R.B., 2004. Possible Late Holocene equatorial palaeoclimate record based upon soils spanning the Medieval Warm Period and Little Ice Age, Loboi Plain, Kenya. Palaeogeography, Palaeoclimatology, Palaeoecology 213, 231-250.

Dunbar, R.B., Cole, J.E., 1999. Annual records of tropical systems (ARTS). PAGES Workshop Report. 
Dunwiddie, P.W., LaMarche, V.C., 1980. A climatically responsive tree-ring record from Widdringtonia cedarbergensis, Cape Province, South Africa. Nature 286, 796-797.

Ekblom, A., Gillson, L., Risberg, J., Holmgren, K., Chidoub, Z., 2012. Rainfall variability and vegetation dynamics of the lower Limpopo Valley, Southern Africa, 500 AD to present. Palaeogeography, Palaeoclimatology, Palaeoecology 363-364, 69-78.

Farmer, E.C., deMenocal, P.B., Marchitto, T.M., 2005. Holocene and deglacial ocean temperature variability in the Benguela upwelling region: implications for low-latitude atmospheric circulation. Paleoceanography 20, doi:10.1029/2004PA001049.

Foerster, V., Vogelsang, R., Junginger, A., Asrat, A., Lamb, H., Schaebitz, F., Trauth, M.H., 2015. Environmental change and human occupation of southern Ethiopia and northern Kenya during the last 20,000 years. Quaternary Science Reviews 129, 333-340.

Foerster, V., Junginger, A., Langkamp, O., Gebru, T., Asrat, A., Umer, M., Lamb, H.F., Wennrich, V., Rethemeyer, J., Nowaczyk, N., Trauth, M.H., Schaebitz, F., 2012. Climatic change recorded in the sediments of the Chew Bahir basin, southern Ethiopia, during the last 45,000 years. Quaternary International 274, 25-37.

Fraedrich, K., Jiang, J.M., Gerstengarbe, F.W., Werner, P.C., 1997. Multiscale detection of abrupt climate changes: application to River Nile flood levels. International Journal of Climatology 17, 1301-1315.

Funk, C., Michaelsen, J., Marshall, M., 2012. Mapping recent decadal climate variations in precipitation and temperature across eastern Africa and the Sahel, in: Wardlow, B., Anderson, M., Verdin, J. (Eds.), Remote Sensing of Drought: Innovative Monitoring Approaches, Cambridge, pp. 331-358.

Funk, C., Dettinger, M.D., Michaelsen, J.C., Verdin, J.P., Brown, M.E., Barlow, M., Hoell, A., 2008. Warming of the Indian Ocean threatens eastern and southern African food security but could be mitigated by agricultural development. Proceedings of the National Academy of Sciences of the United States of America 105, 11081-11086.

Funk, C., Husak, G., Michaelsen, J., Shukla, S., Hoell, A., Lyon, B., Hoerling, M.P., Liebmann, B., Zhang, T., Verdin, J., Galu, G., Eilerts, G., Rowland, J., 2013. Attribution of 2012 and 2003-12 rainfall deficits in eastern Kenya and southern Somalia, in: Peterson, T.C., Hoerling, M.P., Stott, P.A., Herring, S.C. (Eds.), Explaining Extreme Events of 2012 from a Climate Perspective. Bulletin of the American Meteorological Society 94, S45-S48.

Gasse, F., 2000. Hydrological changes in the African tropics since the Last Glacial Maximum. Quaternary Science Reviews 19, 189-211.

Gasse, F., van Campo, E., 1994. Abrupt postglacial climate events in west Asia and northAfrica monsoon domains. Earth and Planetary Science Letters 126, 435-456.

Giannini, A., Saravanan, R., Chang, P., 2003. Oceanic forcing of Sahel rainfall on interannual to interdecadal time scales. Science 302, 1027-1030.

Goddard, L., Graham, N.E., 1999. Importance of the Indian Ocean for simulating rainfall anomalies over eastern and southern Africa. Journal of Geophysical Research 104, 19099-19116.

Halfman, J.D., Johnson, T.C., Finney, B.P., 1994. New AMS dates, stratigraphic correlations and decadal climatic cycles for the past 4 ka at Lake Turkana, Kenya. Palaeogeography, Palaeoclimatology, Palaeoecology 111, 83-98.

Hannaford, M.J., Nash, D.J., 2016. Climate, history, society over the last millennium in southeast Africa. WIREs Climate Change 7, 370-392.

Hannaford, M.J., Jones, J.M., Bigg, G.R., 2015. Early-nineteenth-century southern African precipitation reconstructions from ships' logbooks. The Holocene 25, 379-390.

Hart, N.C.G., Reason, C.J.C., Fauchereau, N., 2010. Tropical-extratropical interactions over southern Africa: Three cases of heavy summer season rainfall. Monthly Weather Review 138, 2608-2623.

Hartwig, G.W., 1979. Demographic considerations in East Africa during the late nineteenth century. International Journal of African Historical Studies 4, 653-672.

Hassan, F.A., 2007. Extreme Nile floods and famines in Medieval Egypt (AD 930-1500) and their climatic implications. Quaternary International 173-174, 101-112. 
Hastenrath, S., Nicklis, A., Greischar, L., 1993. Atmospheric-hydrospheric mechanisms of climate anomalies in the western equatorial Indian Ocean. Journal of Geophysical Research-Oceans 98, 20219-20235.

Hastenrath, S., Polzin, D., Mutai, C., 2007. Diagnosing the 2005 drought in Equatorial East Africa. Journal of Climate 20, 4628-4637.

Hastenrath, S., Polzin, D., Mutai, C., 2010. Diagnosing the Droughts and Floods in Equatorial East Africa during Boreal Autumn 2005-08. Journal of Climate 23, 813-817.

Hijmans, R., Cameron, S.E., Parra, J.L., Jones, P.G., Jarvis, A., 2005. Very high resolution interpolated climate surfaces for global land areas. International Journal of Climatology 25, 1965-1978.

Hoell, A., Funk, C., 2014. Indo-Pacific sea surface temperature influences on failed consecutive rainy seasons over eastern Africa. Climate Dynamics 43, 1645-1660.

Hoelzmann, P., Keding, B., Berke, H., Kropelin, S., Kruse, H.J., 2001. Environmental change and archaeology: lake evolution and human occupation in the Eastern Sahara during the Holocene. Palaeogeography, Palaeoclimatology, Palaeoecology 169, 193-217.

Hoerling, M., Hurrell, J., Eischeid, J., Phillips, A., 2006. Detection and attribution of twentiethcentury northern and southern African rainfall change. Journal of Climate 19, 3989-4008.

Holmes, J.A., Allen, M.J., Street-Perrott, F.A., Ivanovich, M., Perrott, R.A., Waller, M.P., 1999. Late Holocene palaeolimnology of Bal Lake, Northern Nigeria, a multidisciplinary study. Palaeogeography, Palaeoclimatology, Palaeoecology 148, 169-185.

Holmgren, K., Lee-Thorp, J.A., Cooper, G.R.J., Lundblad, K., Partridge, T.C., Scott, L., Sithaldeen, R., Talma, A.S., Tyson, P.D., 2003. Persistent millennial-scale climatic variability over the past 25,000 years in Southern Africa. Quaternary Science Reviews 22, 2311-2326.

Holmgren, K., Karlen, W., Lauritzen, S.E., Lee-Thorp, J.A., Partridge, T.C., Piketh, S., Repinski, P., Stevenson, C., Svanered, O., Tyson, P.D., 1999. A 3000-year highresolution stalagmite-based record of palaeoclimate for northeastern South Africa. The Holocene 9, 295-309.

Holz, C., Stuut, J.-B.W., Henrich, R., Meggers, H., 2007. Variability in terrigenous sedimentation processes off northwest Africa and its relation to climate changes: inferences from grain-size distributions of a Holocene marine sediment record. Sedimentary Geology 202, 499-508.

Hulme, M., Doherty, R., Ngara, T., New, M., Lister, D., 2001. African climate change: 19002100. Climate Research 17, 145-168.

Iliffe, J., 1987. The African Poor: A History. Cambridge University Press, Cambridge.

Jackson, B., Nicholson, S.E., Klotter, D., 2009. Mesoscale convective systems over western Equatorial Africa and their relationship to large-scale circulation. Monthly Weather Review 137, 1272-1294.

Johnson, T.C., Barry, S., Chan, Y., Wilkinson, P., 2001. Decadal record of climate variability spanning the last 700 years in the southern tropics of East Africa. Geology 29, 83-86.

Jones, P.D., Mann, M.E., 2004. Climate over past millennia. Reviews of Geophysics 42, RG2002, doi: 10.1029/2003RG000143.

Jones, P.D., Osborn, T.J., Briffa, K.R., 2001. The evolution of climate over the last millennium. Science 292, 662-667.

Joussaume, S., Taylor, K.E., Braconnot, P., Mitchell, J.F.B., Kutzbach, J.E., Harrison, S.P., Prentice, I.C., Broccoli, A.J., Abe-Ouchi, A., Bartlein, P.J., Bonfils, C., Dong, B., Guiot, J., Herterich, K., Hewitt, C.D., Jolly, D., Kim, J.W., Kislov, A., Kitoh, A., Loutre, M.F., Masson, V., McAvaney, B., McFarlane, N., de Noblet, N., Peltier, W.R., Peterschmitt, J.Y., Pollard, D., Rind, D., Royer, J.F., Schlesinger, M.E., Syktus, J., Thompson, S., Valdes, P., Vettoretti, G., Webb, R.S., Wyputta, U., 1999. Monsoon changes for 6000 years ago: results of 18 simulations from the Paleoclimate Modeling Intercomparison Project (PMIP). Geophysical Research Letters 26, 859-862.

Kelso, C., Vogel, C.H., 2007. The climate of Namaqualand in the nineteenth century. Climatic Change 83, 257-380.

Kiage, L.M., Liu, K.-B., 2009. Palynological evidence of climate change and land degradation in the Lake Baringo area, Kenya, East Africa, since AD 1650. Palaeogeography, Palaeoclimatology, Palaeoecology 279, 60-72. 
Kijazi, A.L., Reason, C.J.C., 2009. Analysis of the 2006 floods over northern Tanzania. International Journal of Climatology 29, 955-970.

Kim, S.T., O'Neil, J.R., 1997. Equilibrium and nonequilibrium oxygen isotope effects in synthetic carbonates. Geochimica Et Cosmochimica Acta 61, 3461-3475.

Knippertz, P., Martin, J.E., 2005. Tropical plumes and extreme precipitation in subtropical and tropical West Africa. Quarterly Journal of the Royal Meteorological Society 112, 2337-2365.

Knippertz, P., Martin, J.E., 2007. The role of dynamic and diabatic processes in the generation of cut-off lows over Northwest Africa. Meteorology and Atmospheric Physics 96, 3-19.

Kondrashov, D., Feliks, Y., Ghil, M., 2005. Oscillatory modes of extended Nile River records (AD 622-1922). Geophysical Research Letters 32, doi: 10.1029/2004gl022156.

Konecky, B., Russell, J., Huang, Y., Vuille, M., Cohen, L., Street-Perrott, F.A., 2014. Impact of monsoons, temperature, and $\mathrm{CO} 2$ on the rainfall and ecosystems of Mt. Kenya during the Common Era. Palaeogeography, Palaeoclimatology, Palaeoecology 396, 17-25.

Krapf, J.L., 1860. Travels, Researches and Missionary Labours, During an Eighteen Years' Residence in Eastern Africa. Trübner and Co., London.

Kröpelin, S., Verschuren, D., Lézine, A.-M., Eggermont, H., Cocquyt, C., Francus, P., Cazet, J.P., Fagot, M., Rumes, B., Russell, J.M., Darius, F., Conley, D.J., Schuster, M., von Suchodoletz, H., Engstrom, D.R., 2008. Climate-driven ecosystem succession in the Sahara: the past 6000 years. Science 320, 765-768.

Kutzbach, J.E., 1981. Monsoon climate of the early Holocene: climate experiment with the Earth's orbital parameters for 9000 years ago. Science 214, 59-61.

Kutzbach, J.E., Otto-Bliesner, B., 1982. The sensitivity of the African-Asian monsoon climate to orbital parameter changes for 9000 years BP in a low-resolution general circulation model. Journal of Atmospheric Science 39, 1177-1188.

Kutzbach, J.E., Liu, Z., 1997. Response of the African Monsoon to orbital forcing and ocean feedbacks in the middle Holocene. Science 278, 440-443.

Lamb, H., Darbyshire, L., Verschuren, D., 2003. Vegetation response to rainfall variation and human impact in central Kenya during the past 1100 years. The Holocene 13, 285-292.

Lamb, H.F., Leng, M.J., Telford, R.J., Ayenew, T., Umer, M., 2007. Oxygen and carbon isotope, composition of authigenic carbonate from an Ethiopian lake: a climate record of the last 2000 years. The Holocene 17, 517-526.

Lee-Thorp, J.A., Hohngren, K., Lauritzen, S.-E., Linge, H., Moberg, A., Partridge, T.C., Stevenson, C., Tyson, P.D., 2001. Rapid climate shifts in the southern African interior throughout the mid- to late Holocene. Geophysical Research Letters 28, 4507-4510.

Legesse, D., Gasse, F., Radakovitch, O., Vallet-Coulomb, C., Bonnefille, R., Verschuren, D. Gibert, E., Barker, P., 2002. Environmental changes in a tropical lake (Lake Abiyata, Ethiopia) during recent centuries. Palaeogeography, Palaeoclimatology, Palaeoecology 187, 233-258.

Levin, N.E., Zipser, E.J., Cerling, T.E., 2009. Isotopic composition of waters from Ethiopia and Kenya: Insights into moisture sources for eastern Africa. Journal of Geophysical Research-Atmospheres 114, doi: 10.1029/2009jd012166.

Lézine, A.-M., Zheng, W., Braconnot, P., Krinner, G., 2011a. Late Holocene plant and climate evolution at Lake Yoa, northern Chad: pollen data and climate simulations. Climate of the Past 7, 1351-1362.

Lézine, A.-M., Hély, C., Grenier, C., Braconnot, P., Krinner, G., 2011b. Sahara and Sahel vulnerability to climate changes, lessons from paleohydrological data. Quaternary Science Reviews 30, 3001-3012.

Lézine, A.-M., Assi-Kaudjhis, C., Roche, E., Vincens, A., Achoundong, G., 2013. Towards an understanding of West African montane forest response to climate change. Journal of Biogeography 40, 183-196.

Liebmann, B., Hoerling, M.P., Funk, C., Blade, I., Dole, R.M., Allured, D., Quan, X.W., Pegion, P., Eischeid, J.K., 2014. Understanding Recent Eastern Horn of Africa Rainfall Variability and Change. Journal of Climate 27, 8630-8645.

Lindesay, J.A., Harrison, M.S.J., Haffner, M.P., 1986. The Southern Oscillation and South African rainfall. South African Journal of Science 82, 196-197. 
Liu, Z., Harrison, S.P., Otto-Bliesner, B., 2004. Global monsoons in the mid-Holocene and oceanic feedback. Climate Dynamics 22, 157-182.

Losada, T., Rodriguez-Fonseca, B., Janicot, S., Gervois, S., Chauvin, F., Ruti, P., 2010. A multi-model approach to the Atlantic Equatorial mode: impact on the West African monsoon. Climate Dynamics 35, 29-43.

Losada, T., Rodriguez-Fonseca, B., Mohino, E., Bader, J., Janicot, S., Mechoso, C.R., 2012. Tropical SST and Sahel rainfall: A non-stationary relationship. Geophysical Research Letters 39, L12705, doi: 10.1029/2012gl052423.

Lyon, B., DeWitt, D.G., 2012. A recent and abrupt decline in the East African long rains. Geophysical Research Letters 39, L02702, doi: 10.1029/2011gl050337.

Machado, M.J., Perez-Gonzalez, A., Benito, G., 1998. Paleoenvironmental changes during the last $4000 \mathrm{yr}$ in the Tigray, northern Ethiopia. Quaternary Research 49, 312-321.

Maley, J., 1973. Les variations climatiques dans le bassin du Tchad durant le dernier Millenaire, essai d'interpretation climatique de l'Holocene. Comptes Rendus de l'Académie des Sciences 276, 1673-1675.

Maley, J., 1976. Mécanisme des changements climatiques aux basses latitudes. Paleogeography, Paleoclimatology, Palaeoecology 14, 193-227.

Maley, J., 1981. Etudes palynologiques dans le basin du Tchad et paleoclimatologie de l'Afrique nord-tropicale de 30.000 ans l'epoque actuelle. Trav. Doc. ORSTOM 129, 1586.

Maley, J., 1989. L'importance de la tradition orale et des donnees historiques pour la reconstitution paleoclimatique du dernier millenaire sur l'Afrique nord-tropicale, Sud Sahara, Sahel Nord, Centre Culturel Francais d'Abijan, pp. 53-57.

Maley, J., 1993. Chronologie calendaire des principales fluctuations du lake Tchad au cours du dernier millenaire I, in: Barreteau, D., Graffenreid, C.V. (Eds.), Datation et Chronologie dans le Bassin du Lac Tchad. ORSTOM, Paris, pp. 161-163.

Mann, M.E., Zhang, Z., Hughes, M.K., Bradley, R.S., Miller, S.K., Rutherford, S., Ni, F., 2008. Proxy-based reconstructions of hemispheric and global surface temperature variations over the past two millennia. Proceedings of the National Academy of Sciences of the United States of America 105, 13252-13257.

Mapande, A.T., Reason, C.J.C., 2005. Links between rainfall variability on intraseasonal and interannual scales over western Tanzania and regional circulation and SST patterns. Meteorology and Atmospheric Physics 89, 215-234.

Marshall, M.H., Lamb, H.F., Davies, S.J., Leng, M.J., Kubsa, Z., Umer, M., Bryant, C., 2009. Climatic change in northern Ethiopia during the past 17,000 years: a diatom and stable isotope record from Lake Ashenge. Palaeogeography, Palaeoclimatology, Palaeoecology 279, 114-127.

Masson-Delmotte, V., Schulz, M., Abe-Ouchi, A., Beer, J., Ganopolski, A., González Rouco, J.F., Jansen, E., Lambeck, K., Luterbacher, J., Naish, T., Osborn, T., Otto-Bliesner, B., Quinn, T., Ramesh, R., Rojas, M., Shao, X., Timmermann, A., 2013. Information from Paleoclimate Archives, in: Stocker, T.F., Qin, D., Plattner, G.-K., Tignor, M., Allen, S.K., Boschung, J., Nauels, A., Xia, Y., Bex, V., Midgley, P.M. (Eds.), Climate Change 2013: The Physical Science Basis. Contribution of Working Group I to the Fifth Assessment Report of the Intergovernmental Panel on Climate Change. Cambridge University Press, Cambridge pp. 383-464.

Matthews, J.A., Briffa, K.R., 2005. The 'Little Ice Age': re-evaluation of an evolving concept. Geografiska Annaler: Series A, Physical Geography 87, 17-36.

Meadows, M.E., Chase, B.M., Seliane, M., 2010. Holocene palaeoenvironments of the Cederberg and Swartruggens mountains, Western Cape, South Africa: pollen and stable isotope evidence from hyrax dung middens. Journal of Arid Environments 74, 786-793.

Miller, J., 1982. The significance of drought, disease and famine in the agriculturally marginal zones of West-Central Africa. Journal of African History 23, 17-61.

Mills, K., Ryves, D.B., Anderson, N.J., Bryant, C.L., Tyler, J.J., 2014. Expressions of climate perturbations in western Ugandan crater lake sediment records during the last 1000 years. Climate of the Past 10, 1581-1601. 
Moberg, A., Sonechkin, D.M., Holmgren, K., Datsenko, N.M., Karlen, W., 2005. Highly variable Northern Hemisphere temperatures reconstructed from low- and high-resolution proxy data. Nature 433, 613-617.

Mohr, K.I., Thorncroft, C.D., 2006. Intense convective systems in West Africa and their relationship to the African easterly jet. Quarterly Journal of the Royal Meteorological Society 132, 163-176.

Mulitza, S., Heslop, D., Pittauerova, D., Fischer, H.W., Meyer, I., Stuut, J.-B., Zabel, M., Mollenhauer, G., Collins, J.A., Kuhnert, H., Schulz, M., 2010. Increase in African dust flux at the onset of commercial agriculture in the Sahel region. Nature 466, 226-228.

Nash, D.J., Endfield, G.H., 2002a. A 19th century climate chronology for the Kalahari region of central southern Africa derived from missionary correspondence. International Journal of Climatology 22, 821-841.

Nash, D.J., Endfield, G.H., 2002b. Historical flows in the dry valleys of the Kalahari identified from missionary correspondence. South African Journal of Science 98, 244-248.

Nash, D.J., Endfield, G.H., 2008. 'Splendid rains have fallen': links between El Nino and rainfall variability in the Kalahari, 1840-1900. Climatic Change 86, 257-290.

Nash, D.J., Grab, S.W., 2010. "A sky of brass and burning winds": documentary evidence of rainfall variability in the Kingdom of Lesotho, Southern Africa, 1824-1900. Climatic Change 101, 617-653.

Nash, D.J., Adamson, G.C.D., 2014. Recent advances in the historical climatology of the tropics and subtropics. Bulletin of the American Meteorological Society 95, 131-146.

Nash, D.J., Meadows, M.E., Gulliver, V.L., 2006. Holocene environmental change in the Okavango Panhandle, northwest Botswana. Quaternary Science Reviews 25, 1302 1322.

Nash, D.J., Pribyl, K., Klein, J., Neukom, R., Endfield, G.H., Adamson, G.C.D., Kniveton, D.R., 2016. Seasonal rainfall variability in southeast Africa during the nineteenth century reconstructed from documentary sources. Climatic Change 134, 605-619.

Nesbitt, S.W., Zipser, E.J., Cecil, D.J., 2000. A census of precipitation features in the tropics using TRMM: Radar, ice scattering, and lightning observations. Journal of Climate 13, 4087-4106.

Neukom, R., Gergis, J., 2012. Southern Hemisphere high-resolution palaeoclimate records of the last 2000 years. The Holocene 22, 501-524.

Neukom, R., Nash, D.J., Endfield, G.H., Grab, S.W., Grove, C.A., Kelso, C., Vogel, C.H., Zinke, J., 2014. Multi-proxy summer and winter precipitation reconstruction for southern Africa over the last 200 years. Climate Dynamics 42, 2713-2716.

Ngomanda, A., Jolly, D., Bentaleb, I., Chepstow-Lusty, A., Makaya, M., Maley, J., Fontugne, M., Oslisly, R., Rabenkogo, N., 2007. Lowland rainforest response to hydrological changes during the last 1500 years in Gabon, Western Equatorial Africa. Quaternary Research 67, 411-425.

Nguetsop, V.F., Servant-Vildary, S., Servant, M., Roux, M., 2010. Long and short-time scale climatic variability in the last 5500 years in Africa according to modern and fossil diatoms from Lake Ossa (Western Cameroon). Global and Planetary Change 72, 356-367.

Nguetsop, V.F., Bentaleb, I., Favier, C., Bietrix, S., Martin, C., Servant-Vildary, S., Servant, M., 2013. A late Holocene palaeoenvironmental record from Lake Tizong, northern Cameroon using diatom and carbon stable isotope analyses. Quaternary Science Reviews 72, 49-62.

Nguetsop, V.F., Bentaleb, I., Favier, C., Martin, C., Bietrix, S., Giresse, P., Servant-Vildary, S., Servant, M., 2011. Past environmental and climatic changes during the last $7200 \mathrm{cal}$ yr BP in Adamawa plateau (Northern-Cameroun) based on fossil diatoms and sedimentary carbon isotopic records from Lake Mbalang. Climate of the Past 7, 13711393.

Nicholson, S.E., 1979. The methodology of historical climate reconstruction and its application to Africa. Journal of African History 20, 31-49.

Nicholson, S.E., 1980. Saharan climates in historic times, in: Williams, M.A.J., Faure, H. (Ed.), The Sahara and the Nile. Balkema, Rotterdam, pp. 173-200. 
Nicholson, S.E., 1981. The Historical Climatology of Africa, in: Wigley, T.M.L., Ingram, M.J., Farmer, G. (Eds.), Climate and History. Cambridge University Press, Cambridge, pp. 249-270.

Nicholson, S.E., 1996. Environmental Change within the Historical Period., in: Goudie, A.S., Adams, W. M., and Orme, A. (Ed.), The Physical Geography of Africa. Oxford University Press, Oxford, pp. 60-75.

Nicholson, S.E., 1999. Historical and modern fluctuations of Lakes Tanganyika and Rukwa and their relationship to rainfall variability. Climatic Change 41, 53-71.

Nicholson, S.E., 2000. The nature of rainfall variability over Africa on time scales of decades to millenia. Global and Planetary Change 26, 137-158.

Nicholson, S.E., 2001. Climatic and environmental change in Africa during the last two centuries. Climate Research 17, 123-144.

Nicholson, S.E., 2009. A revised picture of the structure of the "monsoon" and land ITCZ over West Africa. Climate Dynamics 32, 1155-1171.

Nicholson, S.E., 2011. Dryland Climatology. Cambridge University Press, Cambridge.

Nicholson, S.E., 2014a. A detailed look at the recent drought situation in the Greater Horn of Africa. Journal of Arid Environments 103, 71-79.

Nicholson, S.E., 2014b. Spatial teleconnections in African rainfall: A comparison of 19th and 20th century patterns. The Holocene 24, 1840-1848.

Nicholson, S.E., 2015. Long-term variability of the East African 'short rains' and its links to large-scale factors. International Journal of Climatology 35, 3979-3990.

Nicholson, S.E., Kim, E., 1997. The relationship of the El Nino Southern Oscillation to African rainfall. International Journal of Climatology 17, 117-135.

Nicholson, S.E., Selato, J.C., 2000. The influence of La Nina on African rainfall. International Journal of Climatology 20, 1761-1776.

Nicholson, S.E., Yin, X.G., 2001. Rainfall conditions in equatorial East Africa during the nineteenth century as inferred from the record of Lake Victoria. Climatic Change 48, 387398.

Nicholson, S.E., Webster, P.J., 2007. A physical basis for the interannual variability of rainfall in the Sahel. Quarterly Journal of the Royal Meteorological Society 133, 2065-2084.

Nicholson, S.E., Klotter, D., Dezfuli, A.K., 2012a. Spatial reconstruction of semi-quantitative precipitation fields over Africa during the nineteenth century from documentary evidence and gauge data. Quaternary Research 78, 13-23.

Nicholson, S.E., Dezfuli, A.K., Klotter, D., 2012b. A two-century precipitation dataset for the continent of Africa. Bulletin of the American Meteorological Society 93, 1219-1231.

Nicholson, S.E., Nash, D.J., Chase, B.M., Grab, S.W., Shanahan, T.M., Verschuren, D., Asrat, A., Lézine, A.-M., Umer, M., 2013. Temperature variability over Africa during the last 2000 years. The Holocene 23, 1085-1094.

Norrgård, S., 2015. Practising historical climatology in West Africa: a climatic periodisation 1750-1800. Climatic Change 129, 131-143.

Obwang, B.A., Chen, H., Li, X., Gao, C., 2014. The influence of topography on East Africa October to December climate: Sensitivity experiments with regCM4. Advances in Meteorology 2014, doi: 10.1155/2014/143917.

Ogallo, L.J., Janowiak, J.E., Halpert, M.S., 1988. Teleconnection between seasonal rainfall over East Africa and global sea-surface temperature anomalies. Journal of the Meteorological Society of Japan 66, 807-822.

Okoola, R.E., 1999. A diagnostic study of the eastern Africa monsoon circulation during the northern hemisphere spring season. International Journal of Climatology 19, 143-168.

Onywere, S.M., Shisanya, C.A., Obando, J.A., Ndubi, A.O., Masiga, D., Irura, Z., Mariita, N., Maragia, H.O., 2013. Geospatial extent of 2011-2013 flooding from the Eastern African Rift Valley lakes in Kenya and its implication on the ecosystem, The soda lakes of Kenya: their current conservation status and management, Naivasha, Kenya.

Owen, R.B., Crossley, R., Johnson, T.C., Tweddle, D., Kornfield, I., Davison, S., Eccles, D.H., Engstrom, D.E., 1990. Major low-levels of Lake Malawi and their implications for speciation rates in cichlid fishes. Proceedings of the Royal Society Series B-Biological Sciences 240, 519-553. 
PAGES 2k Consortium, 2013. Continental-scale temperature variability during the past two millennia. Nature Geoscience 6, 339-346.

PAGES 2k Consortium, 2015. Corrigendum: Continental-scale temperature variability during the past two millennia. Nature Geoscience 8, 981-982.

Pankhurst, R., 1966. The great Ethiopian famine of 1888-1892: A new assessment. Journal of the history of medicine and allied sciences $21,95-124$.

Pohl, B., Camberlin, P., 2011. Intraseasonal and interannual zonal circulations over the Equatorial Indian Ocean. Theoretical and Applied Climatology 104, 175-191.

Preston-Whyte, R.A., Tyson, P.D., 1993. The Atmosphere and Weather of Southern Africa. Oxford University Press, Cape Town.

Reason, C.J.C., Mulenga, H., 1999. Relationships between South African rainfall and SST anomalies in the southwest Indian Ocean. International Journal of Climatology 19, 16511673.

Reason, C.J.C., Jagadheesha, D., 2005. Relationships between South Atlantic SST variability and atmospheric circulation over the South African region during austral winter. Journal of Climate, 3339-3355.

Renssen, H., Brovkin, V., Fichefet, T., Goosse, H., 2006. Simulation of the Holocene climate evolution in Northern Africa: the termination of the African Humid Period. Quaternary International 150, 95-102.

Repinski, P., Holmgren, K., Lauritzen, S.E., Lee-Thorp, J.A., 1999. A late Holocene climate record from a stalagmite, Cold Air Cave, Northern Province, South Africa.

Palaeogeography, Palaeoclimatology, Palaeoecology 150, 269-277.

Rowell, D.P., 2003. The impact of Mediterranean SSTs on the Sahelian rainfall season. Journal of Climate 16, 849-862.

Rozanski, K., Araguas-Araguas, L., Gonfiantini, R., 1992. Relation between long-term trends of oxygen-18 isotope composition of precipitation and climate. Science 258, 981-985.

Russell, J.M., Johnson, T.C., 2005. A high resolution geochemical record from Lake Edward, Uganda-Congo, and the timing and causes of tropical African drought during the late Holocene. Quaternary Science Reviews 24, 1375-1389.

Russell, J.M., Johnson, T.C., 2007. Little Ice Age drought in equatorial Africa: Intertropical Convergence Zone migrations and EI Nino-Southern Oscillation variability. Geology 35, 21-24.

Russell, J.M., Verschuren, D., Eggermont, H., 2007. Spatial complexity of 'Little Ice Age' climate in East Africa: sedimentary records from two crater lake basins in western Uganda. The Holocene 17, 183-193.

Saji, N.H., Goswami, B.N., Vinayachandran, P.N., Yamagata, T., 1999. A dipole mode in the tropical Indian Ocean. Nature 401, 360-363.

Schefuß, E., Schouten, S., Schneider, R.R., 2005. Climatic controls on central African hydrology during the past 20,000 years. Nature 437, 1003-1006.

Schefuß, E., Kuhlmann, H., Mollenhauer, G., Prange, M., Patzold, J., 2011. Forcing of wet phases in southeast Africa over the past 17,000 years. Nature 480, 509-512.

Schneider, T., Bischoff, T., Haug, G.H., 2014. Migrations and dynamics of the intertropical convergence zone. Nature 513, 45-53.

Scott, L., 1982. A late Quaternary pollen record from the Transvaal bushveld, South Africa. Quaternary Research 17, 339-370.

Scott, L., 1996. Palynology of hyrax middens: 2000 years of palaeoenvironmental history in Namibia. Quaternary International 33, 73-79.

Scott, L., 1999. Vegetation history and climate in the Savanna biome South Africa since 190,000 ka: a comparison of pollen data from the Tswaing Crater (the Pretoria Saltpan) and Wonderkrater. Quaternary International 57-8, 215-223.

Sene, K.J., Plinston, D.T., 1994. A review and update of the hydrology of Lake Victoria in East Africa. Hydrological Sciences Journal 39, 47-63.

Shanahan, T.M., Overpeck, J.T., Anchukaitis, K.J., Beck, J.W., Cole, J.E., Dettman, D.L., Peck, J., Scholz, C.A., King J.W., 2009. Atlantic forcing of persistent drought in West Africa. Science 324, 377-380. 
Shanahan, T.M., McKay, N.P., Hughen, K.A., Overpeck, J.T., Otto-Bliesner, B., Heil, C.W., King, J., Scholz, C.A., Peck, J., 2015. The time-transgressive termination of the African Humid Period. Nature Geoscience 8, 140-144.

Shongwe, M.E., van Oldenborgh, G.J., van den Hurk, B., van Aalst, M., 2011. Projected changes in mean and extreme precipitation in Africa under global warming. Part II: East Africa. Journal of Climate 24, 3718-3733.

Sletten, H.R., Railsback, L.B., Liang, F., Brook, G.A., Marais, E., Hardt, B.F., Cheng, H., Edwards, R.L., 2013. A petrographic and geochemical record of climate change over the last 4600 years from a northern Namibia stalagmite, with evidence of abruptly wetter climate at the beginning of southern Africa's Iron Age. Palaeogeography, Palaeoclimatology, Palaeoecology 376, 149-162.

Stager, J.C., Cumming, B.F., Meeker, L.D., 2003. A 10,000-year high-resolution diatom record from Pilkington Bay, Lake Victoria, East Africa. Quaternary Research 59, 172181.

Stager, J.C., Ryves, D., Cumming, B.F., Meeker, L.D., Beer, J., 2005. Solar variability and the levels of Lake Victoria, East Africa, during the last millenium. Journal of Paleolimnology 33, 243-251.

Stager, J.C., Cocquyt, C., Bonnefille, R., Weyhenmeyer, C., Bowerman, N., 2009. A late Holocene paleoclimatic history of Lake Tanganyika, East Africa. Quaternary Research 72, 47-56.

Stager, J.C., Ryves, D.B., King, C., Madson, J., Hazzard, M., Neumann, F.H., Maud, R., 2013. Late Holocene precipitation variability in the summer rainfall region of South Africa. Quaternary Science Reviews 67, 105-120.

Stager, J.C., Mayewski, P.A., White, J., Chase, B.M., Neumann, F.H., Meadows, M.E., King, C.D., Dixon, D.A., 2012. Precipitation variability in the winter rainfall zone of South Africa during the last $1400 \mathrm{yr}$ linked to the austral westerlies. Climate of the Past 8, 877-887.

Stevenson, C., Lee-Thorp, J.A., Holmgren, K., 1999. A 3000-year isotopic record from a stalagmite in Cold Air Cave, Makapansgat Valley, Northern Province. South African Journal of Science 95, 46-48.

Stockhall, S., 2010. A wetter Botswana? Peolwane, 22-24.

Street-Perrott, F.A., Perrott, R.A., 1990. Abrupt climate fluctuations in the tropics: the influence of Atlantic Ocean circulation. Nature 343, 607-612.

Street-Perrott, F.A., Homes, J.A., Waller, M.P., Allen, M.J., Barber, N.G.H., Fothergill, P.A., Harkness, D.D., Ivanovich, M., Kroon, D., Perrott, R.A., 2000. Drought and dust deposition in the West African Sahel: a 5500-year record from Kajemarum Oasis, northeastern Nigeria. The Holocene 10, 293-302.

Sundqvist, H.S., Holmgren, K., Fohlmeister, J., Zhang, Q., Bar-Matthews, M., Spötl, C., Körnich, H., 2013. Evidence of a large cooling between 1690 and 1740 AD in southern Africa. Scientific Reports 3, doi: 10.1038/srep01767.

Sutcliffe, J.V., Parks, Y.P., 1999. The East African lakes below Lake Victoria, The hydrology of the Nile. International Association of Hydrological Sciences Special Publication No. 5, pp. 37-56.

Talma, A.S., Vogel, J.C., 1992. Late Quaternary paleotemperatures derived from a speleothem from Cango Caves, Cape Province, South Africa. Quaternary Research 37, 203-213.

Thackeray, J.F., 1999. Calibration of temperature indices from a late Quaternary terrestrial sequence at Wonderkrater, South Africa. Quaternary International 57-58, 225-227.

Therrell, M.D., Stahle, D.W., Ries, L.P., Shugart, H.H., 2006. Tree-ring reconstructed rainfall variability in Zimbabwe. Climate Dynamics 26, 677-685.

Thompson, L.G., Mosley-Thompson, E., Davis, M.E., Henderson, K.A., Brecher, H.H., Zagorodnov, V.S., Mashiotta, T.A., Lin, P.-N., Mikhalenko, V.N., Hardy, D.R., Beer, J., 2002. Kilimanjaro ice core records: evidence of Holocene climate change in tropical Africa. Science 298, 589-593.

Thorncroft, C.D., Hanh, N., Zhang, C., Peyrille, P., 2011. Annual cycle of the West African monsoon: regional circulations and associated water vapour transport. Quarterly Journal of the Royal Meteorological Society 137, 129-147. 
Tierney, J.E., deMenocal, P.B., 2013. Abrupt shifts in Horn of Africa hydroclimate since the Last Glacial Maximum. Science 342, 843-846.

Tierney, J.E., Ummenhofer, C.C., deMenocal, P.B., 2015. Past and future rainfall in the Horn of Africa. Science Advances 1, e1500682, doi: 10.1126/sciadv.1500682.

Tierney, J.E., Smerdon, J.E., Anchukaitis, K.J., Seager, R., 2013. Multidecadal variability in East African hydroclimate controlled by the Indian Ocean. Nature 493, 389-392.

Tierney, J.E., Russell, J.M., Sinninghe Damsté, J.S., Huang, Y., Verschuren, D., 2011a. Late Quaternary behavior of the East African monsoon and the importance of the Congo Air Boundary. Quaternary Science Reviews 30, 798-807.

Tierney, J.E., Lewis, S.C., Cook, B.I., LeGrande, A.N., Schmidt, G.A., 2011b. Model, proxy and isotopic perspectives on the East African Humid Period. Earth and Planetary Science Letters 307, 103-112.

Tierney, J.E., Russell, J.M., Huang, Y., Damste, J.S.S., Hopmans, E.C., Cohen, A.S., 2008. Northern Hemisphere controls on tropical southeast African climate during the past 60,000 years. Science 322, 252-255.

Todd, M., Washington, R., 1999. Circulation anomalies associated with tropical-temperate troughs in southern Africa and the south west Indian Ocean. Climate Dynamics 15, 937951.

Trabucco, A., Zomer, R.J., 2009. Global Aridity Index (Global-Aridity) and Global Potential Evapo-Transpiration (Global-PET) Geospatial Database. CGIAR-CSI GeoPortal, http://www.csi.cgiar.org.

Truc, L., Chevalier, M., Favier, C., Cheddadi, R., Meadows, M.E., Scott, L., Carr, A.S., Smith, G.F., Chase, B.M., 2013. Quantification of climate change for the last 20,000 years from Wonderkrater, South Africa: Implications for the long-term dynamics of the Intertropical Convergence Zone. Palaeogeography, Palaeoclimatology, Palaeoecology 386, 575-587.

Tyson, P.D., 1986. Climatic Change and Variability in Southern Africa. Oxford University Press, Cape Town.

Tyson, P.D., Lindesay, J.A., 1992. The climate of the last 2000 years in southern Africa. The Holocene 2, 271-278.

Tyson, P.D., Preston-Whyte, R.A., 2000. The Weather and Climate of Southern Africa. Oxford University Press, Cape Town.

Tyson, P.D., Karlen, W., Holmgren, K., Heiss, G.A., 2000. The Little Ice Age and medieval warming in South Africa. South African Journal of Science 96, 121-126.

Umer, M., Lamb, H.F., Bonnefille, R., Lézine, A.M., Tiercelin, J.J., Gibert, E., Cazet, J.P., Watrin, J., 2007. Late Pleistocene and Holocene vegetation history of the Bale Mountains, Ethiopia. Quaternary Science Reviews 26, 2229-2246.

Ummenhofer, C.C., Sen Gupta, A., England, M.H., Reason, C.J.C., 2009. Contributions of Indian Ocean sea surface temperatures to enhanced East African rainfall. Journal of Climate 22, 993-1013.

van Heerden, J., Taljaard, J.J., 1998. Africa and the surrounding waters, in: Karoly, D.J., Vincent, D.G. (Eds.), Meteorology of the Southern Hemisphere. American Meteorological Society, Boston, MA, pp. 141-174.

van Zinderen Bakker, E.M., 1976. The evolution of late Quaternary paleoclimates of Southern Africa. Palaeoecology of Africa 9, 160-202.

Verschuren, D., 1999a. Influence of depth and mixing regime on sedimentation in a small, fluctuating tropical soda lake. Limnology and Oceanography 44, 1103-1113.

Verschuren, D., 1999b. Sedimentation controls on the preservation and time resolution of climate-proxy records from shallow fluctuating lakes. Quaternary Science Reviews 18, 821-837.

Verschuren, D., 2001. Reconstructing fluctuations of a shallow East African lake during the past 1800 yrs from sediment stratigraphy in a submerged crater basin. Journal of Paleolimnology 25, doi: 10.1023/a:1011150300252.

Verschuren, D., 2003. Lake-based climate reconstruction in Africa: progress and challenges. Hydrobiologia 500, 315-330.

Verschuren, D., 2004. Decadal to century-scale climate variability in tropical Africa during the past 2000 years, in: Battarbee, R.W., Gasse, F., Stickley, C. (Eds.), Past climate variability through Europe and Africa. Kluwer, Dordrecht, pp. 139-158. 
Verschuren, D., Charman, D.J., 2008. Latitudinal linkages in late-Holocene moisture-balance variation, in: Battarbee, R., Binney, H. (Eds.), Natural Climate Variability and Global Warming: A Holocene Perspective. Wiley-Blackwell, Chichester, pp. 189-231.

Verschuren, D., Russell, J.M., 2009. Paleolimnology of African lakes: beyond the exploration phase. PAGES News 17, 112-114.

Verschuren, D., Laird, K.R., Cumming, B.F., 2000. Rainfall and drought in equatorial east Africa during the past 1,100 years. Nature 403, 410-414.

Verschuren, D., Tibby, J., Leavitt, P.R., Roberts, C.N., 1999a. The environmental history of a climate-sensitive lake in the former 'White Highlands' of central Kenya. Ambio 28, 494501.

Verschuren, D., Cocquyt, C., Tibby, J., Roberts, C.N., Leavitt, P.R., 1999b. Long-term dynamics of algal and invertebrate communities in a small, fluctuating tropical soda lake. Limnology and Oceanography 44, 1216-1231.

Verschuren, D., Damste, J.S.S., Moernaut, J., Kristen, I., Blaauw, M., Fagot, M., Haug, G.H., CHALLACEA Project Members, 2009. Half-precessional dynamics of monsoon rainfall near the East African Equator. Nature 462, 637-641.

Vincens, A., Schwartz, D., Bertaux, J., Elenga, H., de Namur, C., 1998. Late Holocene climatic changes in western equatorial Africa inferred from pollen from Lake Sinnda, southern Congo. Quaternary Research 50, 34-45.

Vincens, A., Schwartz, D., Elenga, H., Reynaud-Farrera, I., Alexandre, A., Bertaux, J., Mariotti, A., Martin, L., Meunier, J.-D., Nguetsop, F., Servant, M., Servant-Vildary, S., Wirrmann, D., 1999. Forest response to climate changes in Atlantic Equatorial Africa during the last 4000 years BP and inheritance on the modern landscapes. Journal of Biogeography 26, 879-885.

Vincens, A., Buchet, G., Servant, M. \& ECOFIT Mbalang collaborators, 2010. Vegetation response to the "African Humid Period" termination in Central Cameroon $\left(7^{\circ} \mathrm{N}\right)$ - new pollen insight from Lake Mbalang. Climate of the Past 6, 281-294.

Vogel, C.H., 1989. A documentary-derived climatic chronology for South Africa, 1820-1900. Climatic Change 14, 291-307.

Webster, J.B., 1979. Chronology, Migration and Drought in Interlacustrine Africa. Longman \& Dalhousie University Press, London, UK.

Williams, A.P., Funk, C., 2011. A westward extension of the warm pool leads to a westward extension of the Walker circulation, drying eastern Africa. Climate Dynamics 37, 24172435.

Williams, A.P., Funk, C., Michaelsen, J., Rauscher, S.A., Robertson, I., Wils, T.H.G., Koprowski, M., Eshetu, Z., Loader, N.J., 2012. Recent summer precipitation trends in the Greater Horn of Africa and the emerging role of Indian Ocean sea surface temperature. Climate Dynamics 39, 2307-2328.

Wils, T.H.G., Robertson, I., Eshetu, Z., Koprowski, M., Sass-Klaassen, U.G.W., Touchan, R., Loader, N.J., 2010. Towards a reconstruction of Blue Nile baseflow from Ethiopian tree rings. The Holocene 20, 837-848.

Wolde-Georgis, T., 1997. El Niño and Drought Early Warning in Ethiopia, Internet Journal of African Studies 2. Available at SSRN: http://ssrn.com/abstract=1589710.

Wolff, C., Haug, G.H., Timmermann, A., Damste, J.S.S., Brauer, A., Sigman, D.M., Cane, M.A., Verschuren, D., 2011. Reduced interannual rainfall variability in East Africa during the last Ice Age. Science 333, 743-747.

Woodborne, S., Hall, G., Robertson, I., Patrut, A., Rouault, M., Loader, N.J., Hofmeier, M., 2015. A 1000-year carbon isotope rainfall proxy record from South African baobab trees (Adansonia digitata L.). PLoS ONE 10, doi: 10.1371/journal.pone.0124202.

Zhang, C., Woodworth, P., Gu, G., 2006. The seasonal cycle in the lower troposphere over West Africa from sounding observations. Quarterly Journal of the Royal Meteorological Society 132, 2559-2582.

Zhang, R., Delworth, T.L., 2006. Impact of Atlantic multidecadal oscillations on India/Sahel rainfall and Atlantic hurricanes. Geophysical Research Letters 33, doi:

10.1029/2006gl026267. 
Zhou, L., Tian, Y., Myneni, R.B., Ciais, P., Saatchi, S., Liu, Y.Y., Piao, S., Chen, H., Vermote, E.F., Song, C., Hwang, T., 2014. Widespread decline of Congo rainforest greenness in the past decade. Nature 509, 86-90.

Zipser, E.J., Cecil, D.J., Liu, C., Nesbitt, S.W., Yorty, D.P., 2006. Where are the most intense thunderstorms on Earth? Bulletin of the American Meteorological Society 87, 1057-1071. 
Table 1: Locations mentioned in the text and shown on Figure 1.

\begin{tabular}{|c|c|c|c|c|c|}
\hline Location & Code & Long & Lat & Type & Key reference(s) \\
\hline Awdaghast & AW & -10.4458 & 17.38146 & Historical sources & Nicholson (1979) \\
\hline Bougdouma & $\mathrm{BD}$ & 11.6991 & 13.2708 & Lake/wetland sediment & Gasse and van Campo (1994) \\
\hline Cango Cave & $\mathrm{CC}$ & 22.2149 & -33.3923 & Speleothem & Talma and Vogel (1992) \\
\hline Chew Bahir & CB & 36.8681 & 4.9291 & Lake/wetland sediment & Foerster et al. (2012); Foerster et al. (2015) \\
\hline Cold Air Cave & $\mathrm{CaC}$ & 29.1667 & -24.1333 & Speleothem & $\begin{array}{l}\text { Holmgren et al. (1999; 2003); Repinski et al. (1999); } \\
\text { Stevenson et al. (1999); Lee-Thorp et al. (2001) }\end{array}$ \\
\hline Elands Bay & EB & 18.3176 & -32.3176 & Shell midden & Cohen et al. (1992) \\
\hline GeoB9501 & 9501 & -16.7327 & 16.8402 & Marine sediment & Mulitza et al. (2010) \\
\hline Gulf of Aden & $A D$ & 44.3000 & 11.9550 & Marine sediment & Tierney et al. (2015) \\
\hline Kajemarum & $\mathrm{KM}$ & 11.0300 & 13.3100 & Lake/wetland sediment & Street-Perrott et al. (2000) \\
\hline Kuiseb River & $\mathrm{KR}$ & 14.5353 & -23.1153 & Hyrax midden & Scott (1996) \\
\hline Lake Baringo & BR & 36.0676 & 0.6243 & Lake/wetland sediment & Bessems et al. (2008); Kiage and Liu (2009) \\
\hline Lake Bogoria & BG & 36.1002 & 0.2649 & Lake/wetland sediment & De Cort et al. (2013) \\
\hline Lake Bosumtwi & $\mathrm{BO}$ & -1.4145 & 6.5017 & Lake/wetland sediment & Shanahan et al. (2009) \\
\hline Lake Chad & $\mathrm{CH}$ & 14.1001 & 13.3303 & Lake/wetland sediment & Maley $(1973,1981,1989,1993)$ \\
\hline Lake Challa & $\mathrm{CL}$ & 37.6972 & -3.3154 & Lake/wetland sediment & Blaauw et al. (2011); Wolff et al. (2011); Buckles et al. (2016) \\
\hline Lake Edward & ED & 29.6963 & -0.3256 & Lake/wetland sediment & Russell and Johnson (2007) \\
\hline Lake Elementeita & EL & 36.2468 & -0.4431 & Lake/wetland sediment & De Cort et al. (2013) \\
\hline
\end{tabular}




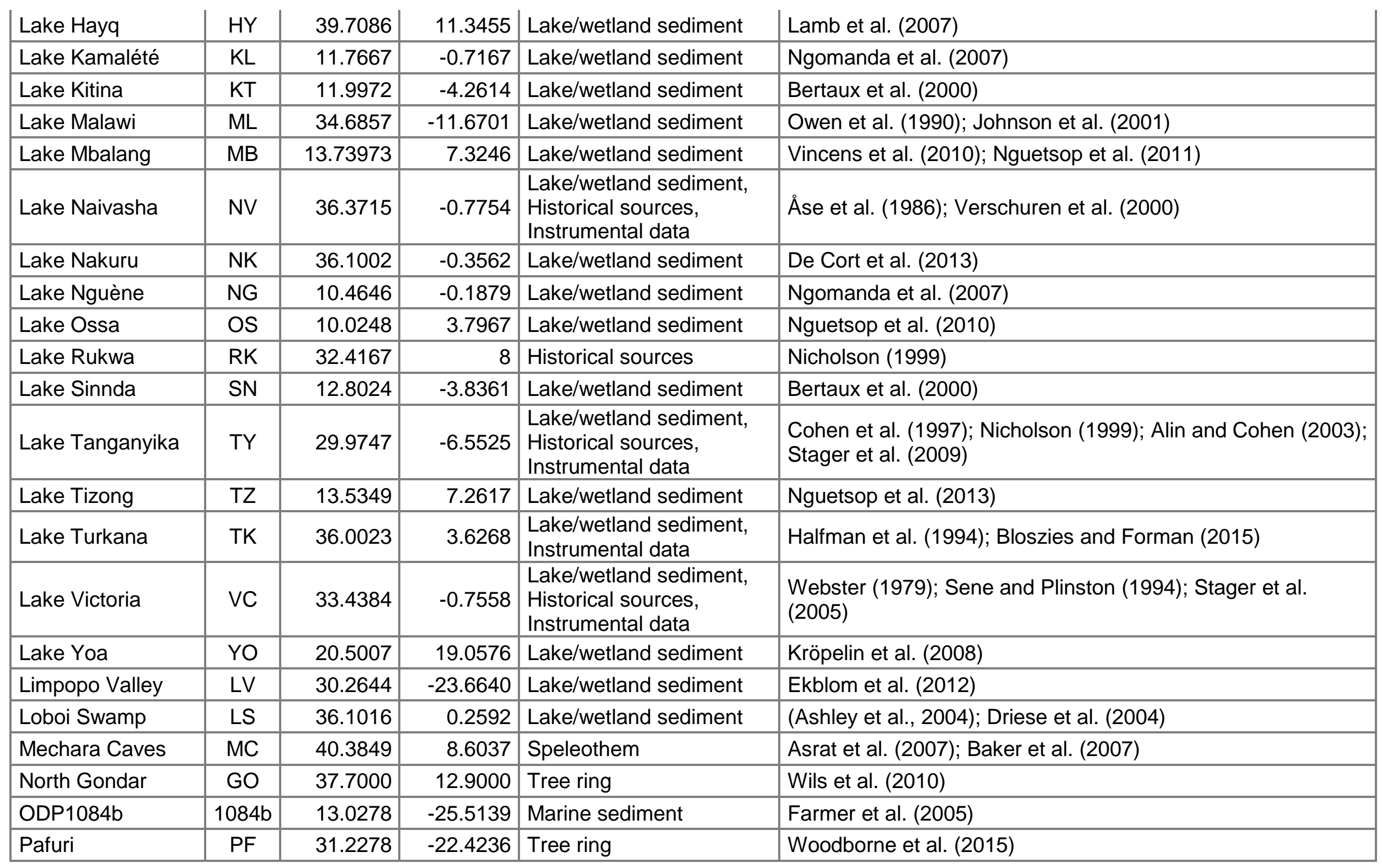




\begin{tabular}{|l|c|r|r|l|l|} 
Pangani Valley & PV & 38.8995 & -5.4023 & Historical sources & Burton (1860) \\
\hline Rao & RA & -16.3994 & 15.9219 & Historical sources & Nicholson (1979) \\
\hline Sacred Lake & SL & 37.5333 & -0.0500 & Lake/wetland sediment & Konecky et al. (2014) \\
\hline Seweweekspoort & SW & 21.3675 & -33.3983 & Hyrax midden & Chase et al. (2013) \\
\hline Spitzkoppe & SP & 15.1942 & -21.8247 & Hyrax midden & Chase et al. (2009) \\
\hline Tassili n'Ajjer & TA & 10.1000 & 24.8000 & Tree ring & Cremaschi et al. (2006) \\
\hline Tibesti & TB & 18.0000 & 20.7161 & Historical sources & Nicholson (1979) \\
\hline $\begin{array}{l}\text { Uganda crater } \\
\text { lakes }\end{array}$ & UCL & 29.9755 & -0.0637 & Lake/wetland sediment & Russell et al. (2007); Bessems et al. (2008); Mills et al. (2014) \\
\hline Verlorenvlei & VV & 18.4187 & -32.3333 & Lake/wetland sediment & Stager et al. (2012) \\
\hline Wonderkrater & WK & 28.7519 & -24.4336 & Lake/wetland sediment & Scott (1982; 1999); Thackeray (1999); Truc et al. (2013) \\
\hline
\end{tabular}




\section{List of Figures}

Figure 1: Aridity index map of Africa (data from Trabucco and Zomer, 2009), with sites described in the text indicated (along with primary record type; see Table 1). Panels below show seasonal distribution of precipitation (data from Hijmans et al., 2005).

Figure 2: Comparison of Northern Hemisphere temperature reconstruction (Moberg et al., 2005) with representative palaeoclimate records from West Africa (see Table 1 for references). The Medieval Climate Anomaly (MCA) and Little Ice Age (LIA) are indicated by red and blue shading, respectively, with the intensity of shading within these periods indicating the strength of the temperature anomaly relative to the average temperatures between 900 and $1900 \mathrm{CE}$.

Figure 3: Comparison of Northern Hemisphere temperature reconstruction (Moberg et al., 2005) with representative palaeoclimate records from eastern Africa (see Table 1 for references). Figure 2 explains shading of Medieval Climate Anomaly (MCA) and Little Ice Age (LIA).

Figure 4: Comparison of Northern Hemisphere temperature reconstruction (Moberg et al., 2005) with representative palaeoclimate records from southern Africa (see Table 1 for references). Figure 2 explains shading of Medieval Climate Anomaly (MCA) and Little Ice Age (LIA).

Figure 5: Regional rainfall anomalies in the 1830s and in the years 1982 to 1984 . The historical anomalies are indicated as an anomaly class, ranging from -3 to +3 , from dry to wet (see Nicholson et al., 2012a). The modern anomalies are regionally averaged standard deviations from the long-term mean for each record. Note that the dry conditions shown for 1982 to 1984 generally characterised most of the 1980 s decade.

Figure 6: Time series of regionally-averaged rainfall for regions of the African continent (see inset map), expressed as standard deviations from the long-term mean in the main rainy season months. Months are indicated at the bottom of each frame. Green bars on the xaxis indicate years with no data.

Figure 7: Comparison of Northern Hemisphere temperature reconstruction (Moberg et al., 2005) with representative palaeoclimate records from across Africa (see Table 1). Figure 2 explains shading of Medieval Climate Anomaly (MCA) and Little Ice Age (LIA).

Figure 8: Map of key palaeoclimate records from Africa. Associated polygons indicate the patterning of arid (brown) and humid (green) hydroclimate anomalies relative to the average conditions between 900 and 1900 CE. The polygons are divided as per the inset depicting Northern Hemispheres temperatures (red=warmer, blue=cooler) over the same period (bottom left; Moberg et al., 2005). For both temperature and hydroclimate 
polygons, each coloured subdivision represents one decade, with the value being derived from a 10-year smoothing of the original datasets. 


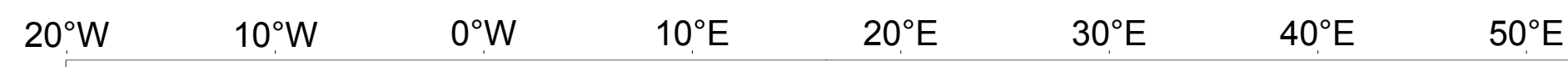
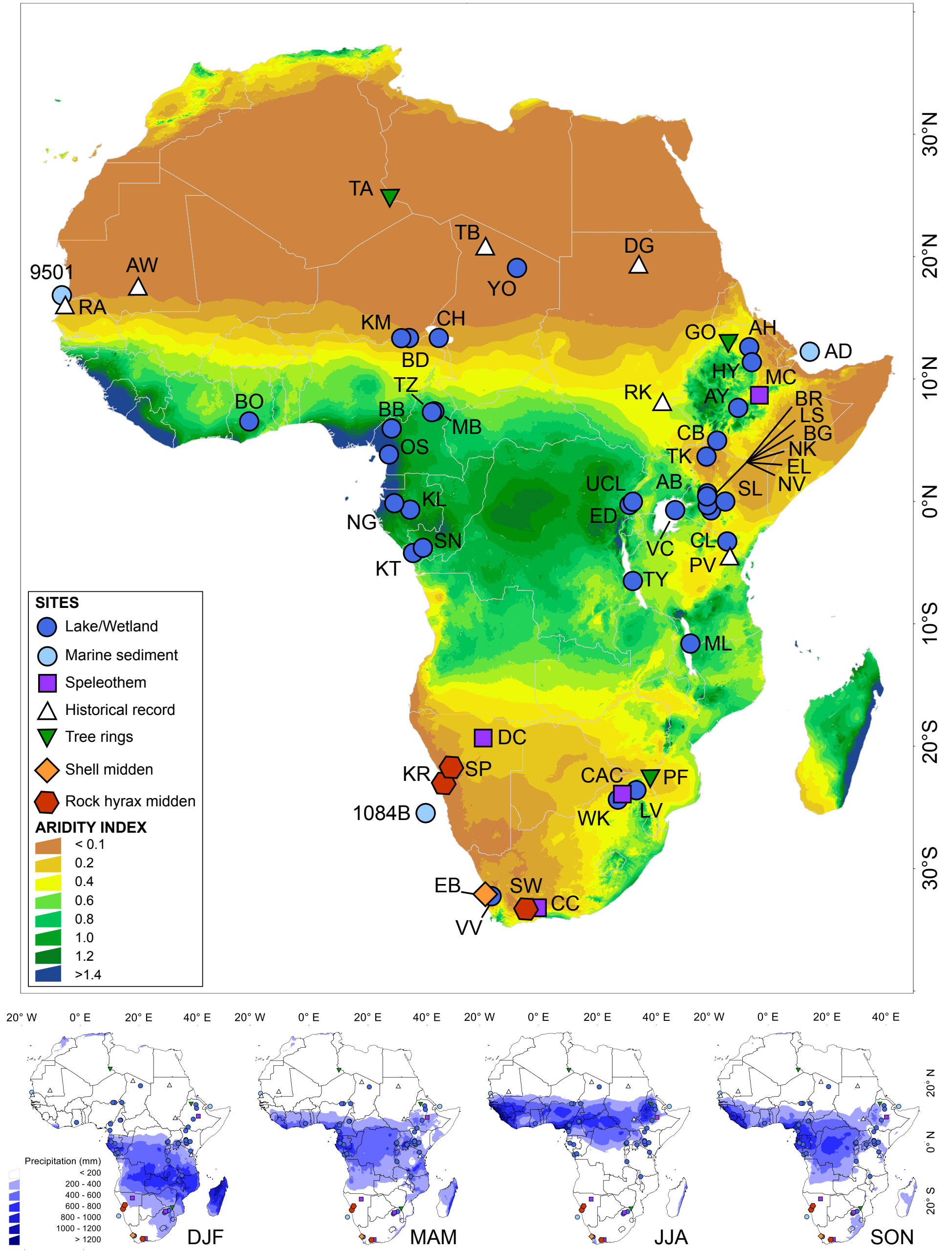
Age (cal yr AD)

$-1000$

$-500$

500

r'MCA' $\risingdotseq$ 'LIA'

Northern Hemisphere

-

20

30

ㅇ 40

50

60

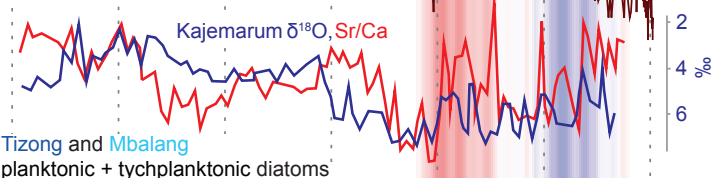

planktonic + tychplanktonic diatoms

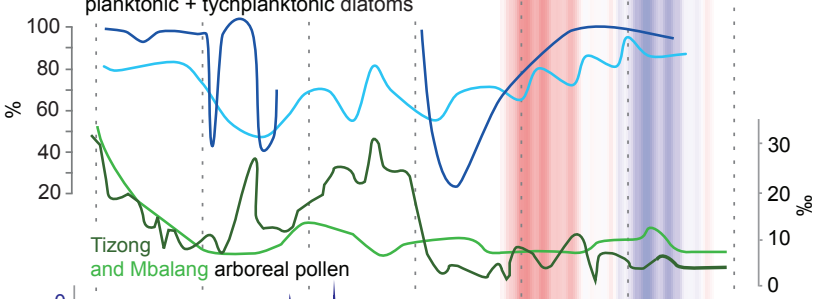

年 2.
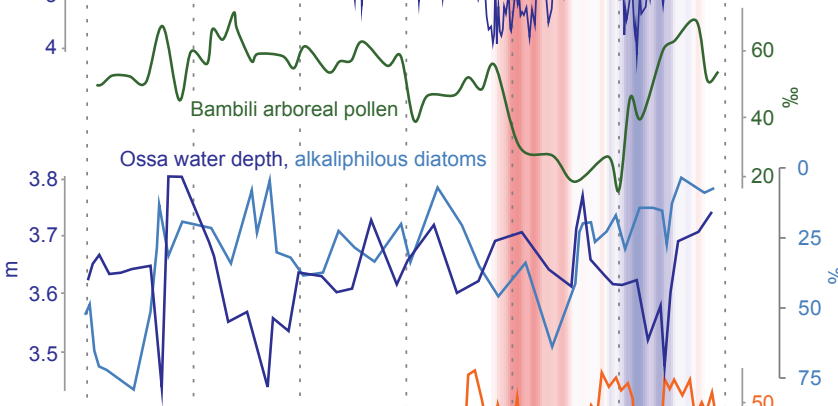

Nguene tree/herb

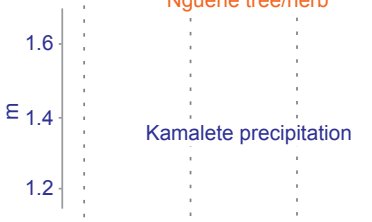

Kitina and Sinnda kaolinite

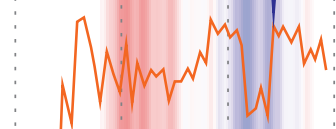

-25 웅

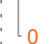

60

$40 \stackrel{\circ}{\circ}$

50

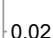

0.02

$0.01 \frac{\frac{\pi}{2}}{\frac{\pi}{0}}$ 


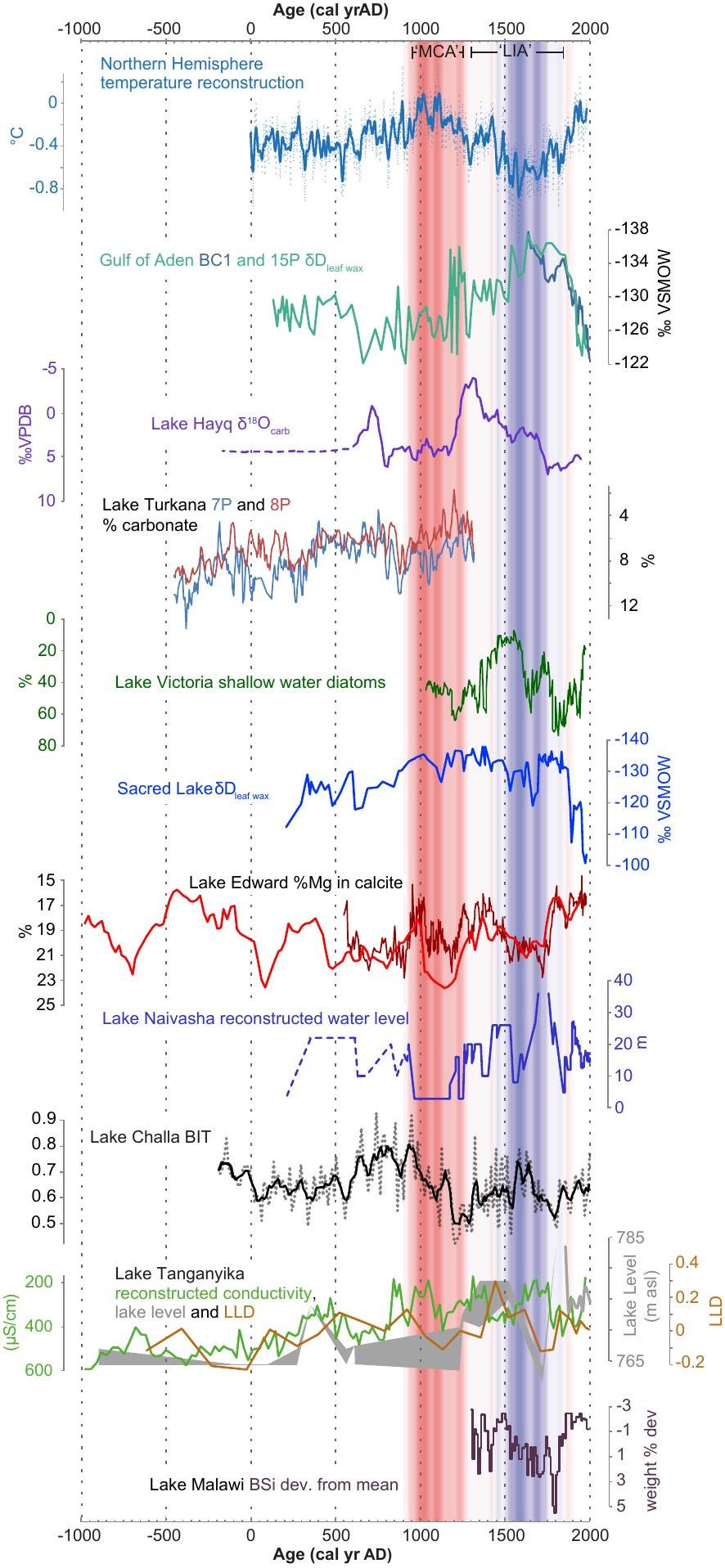




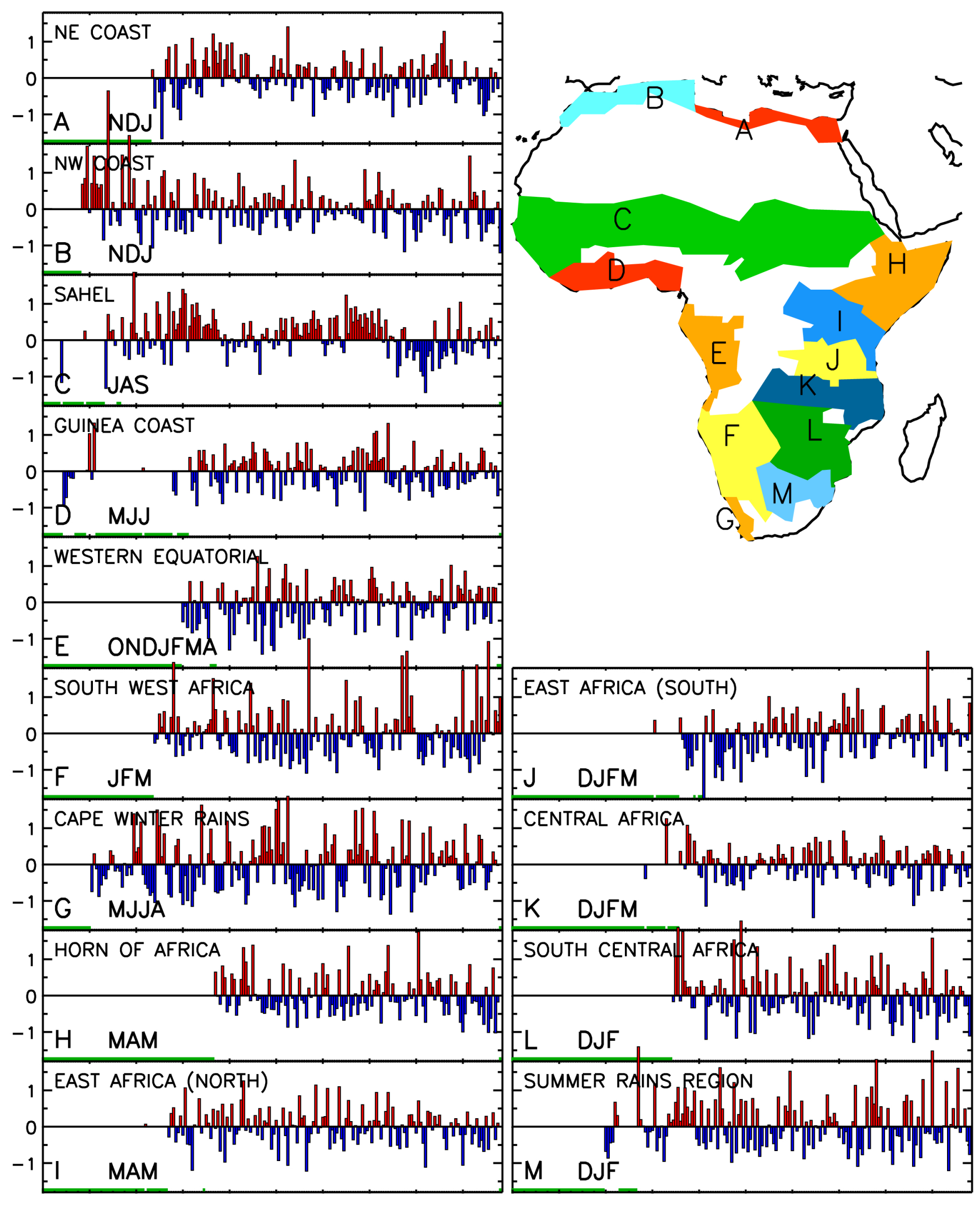

18201840186018801900192019401960198020001820184018601880190019201940196019802000 


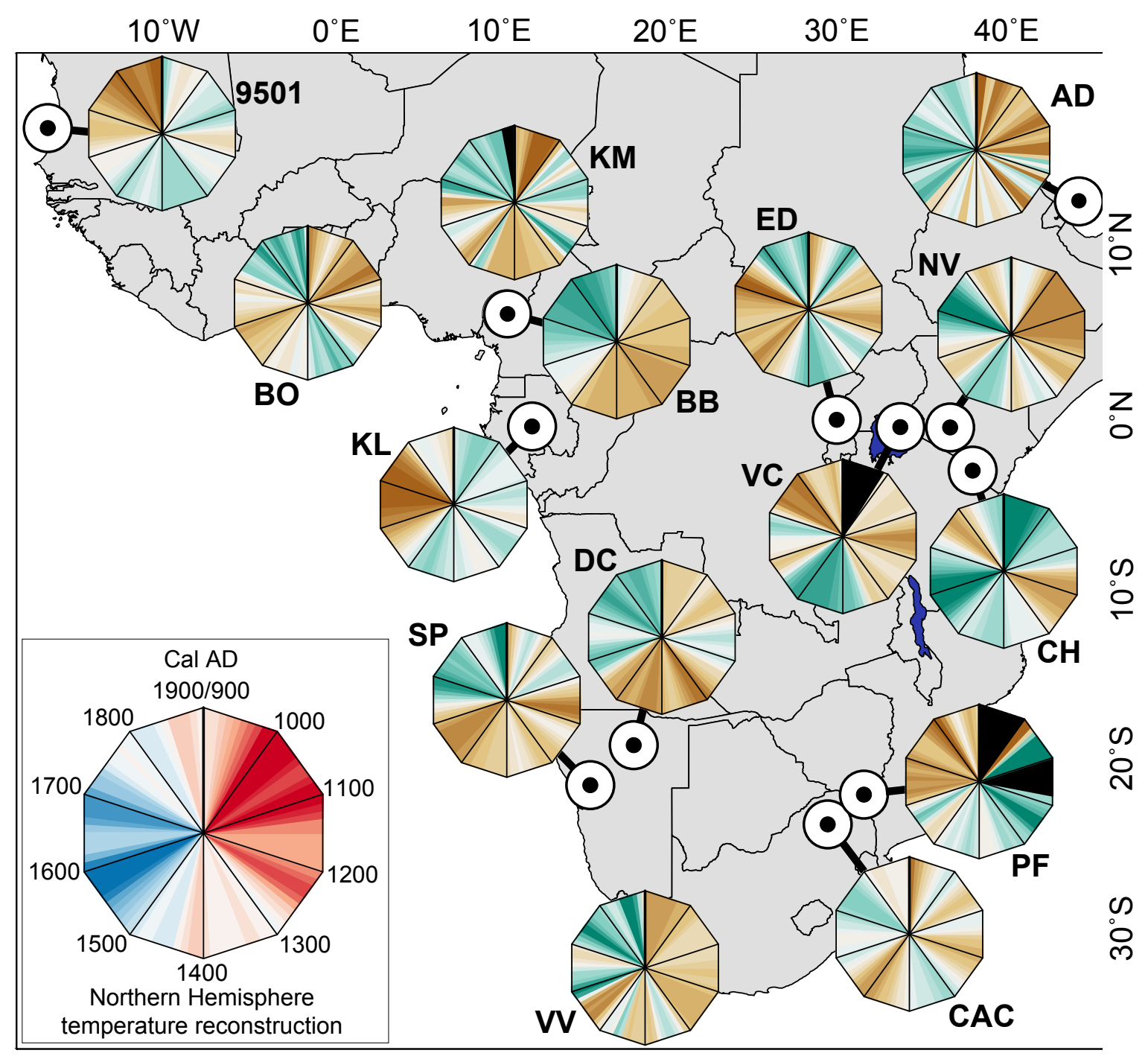

